\title{
Shelter, Knowledge, Activism: A Refuge in the Canadian Forest for Political Exiles and Intellectual Dissidents of Totalitarian Regimes
}

Walter Fu

A thesis submitted to the Faculty of Graduate and Post Doctoral Affairs in partial fulfillment of the requirements for the degree of

Master of Architecture

Carleton University

Ottawa, Ontario

(C) 2021

Walter Fu 


\section{ACKNOWLEDGEMENTS}

To my advisor, Inderbir Singh Riar, I would like to thank you for your dedication to the project, and your belief in me and the ideals and values that the project upholds. Thank you for sharing your experiences, knowledge and enthusiasm throughout this term and for your support in my endeavours, without which this project would not have been possible. Thank you.

To my parents, I would like to thank you for your support and for standing by me throughout all of my schooling, showering me with encouragement every step of the way. Without your help, I would never have made it as far as I have, nor achieved as much as I could. Thank you.

To my extended family, although many of you did not fully understand what research was about, nor what questions my thesis would pose or who it would challenge, you gave me your full support and love, urging me on and encouraging me in every aspect of my work. Thank you.

To my friends, some who are graduating with me, but also many others who have chosen different paths, thank you for your kind words, and encouragement throughout the years. While some have stayed up many late nights with me, and others I only hear from every once in a while, thank you all for having my back, and continuing to be wonderful human beings. 


\section{ABSTRACT}

Issues of civil rights have been thrust into the spotlight due to the events in Hong Kong and China, with numerous attacks against journalists, activists and others who have spoken out against the censorship of free ideas and the ongoing genocide of the Uyghur people in the XUAR.

The project, a retreat for scholars, activists and political refugees, expresses my belief in protecting the intellectual freedoms and the rights of those being persecuted by totalitarian powers for voicing their ideas and opinions. The project seeks to help persecuted intellectuals, journalists, activists and other by working in collaboration with the Carleton University branch of Scholars at Risk, an organization dedicated to protecting threatened scholars, preventing attacks on higher education, and promoting academic freedom and related values worldwide. The project seeks to shelter and nurture these activists and free thinkers who find themselves in political exile, many of whom live in fear of persecution, sheltering from the reach of the Chinese Communist Party (CCP) and other oppressive regimes around the world.

Beyond a remote village in Gatineau Park, the project proposes to burrow itself in the dense forests of the conservation park, removed from the eyes of the city and shrouded in the calming wilderness. The retreat will grant the means and resources for scholars to continue their academic pursuits and activists to continue their work as leaders and free thinkers. It is to be a place to nurture, grow and support individuals in their fight for human and civil rights while building strong lasting relationships throughout their stay. 


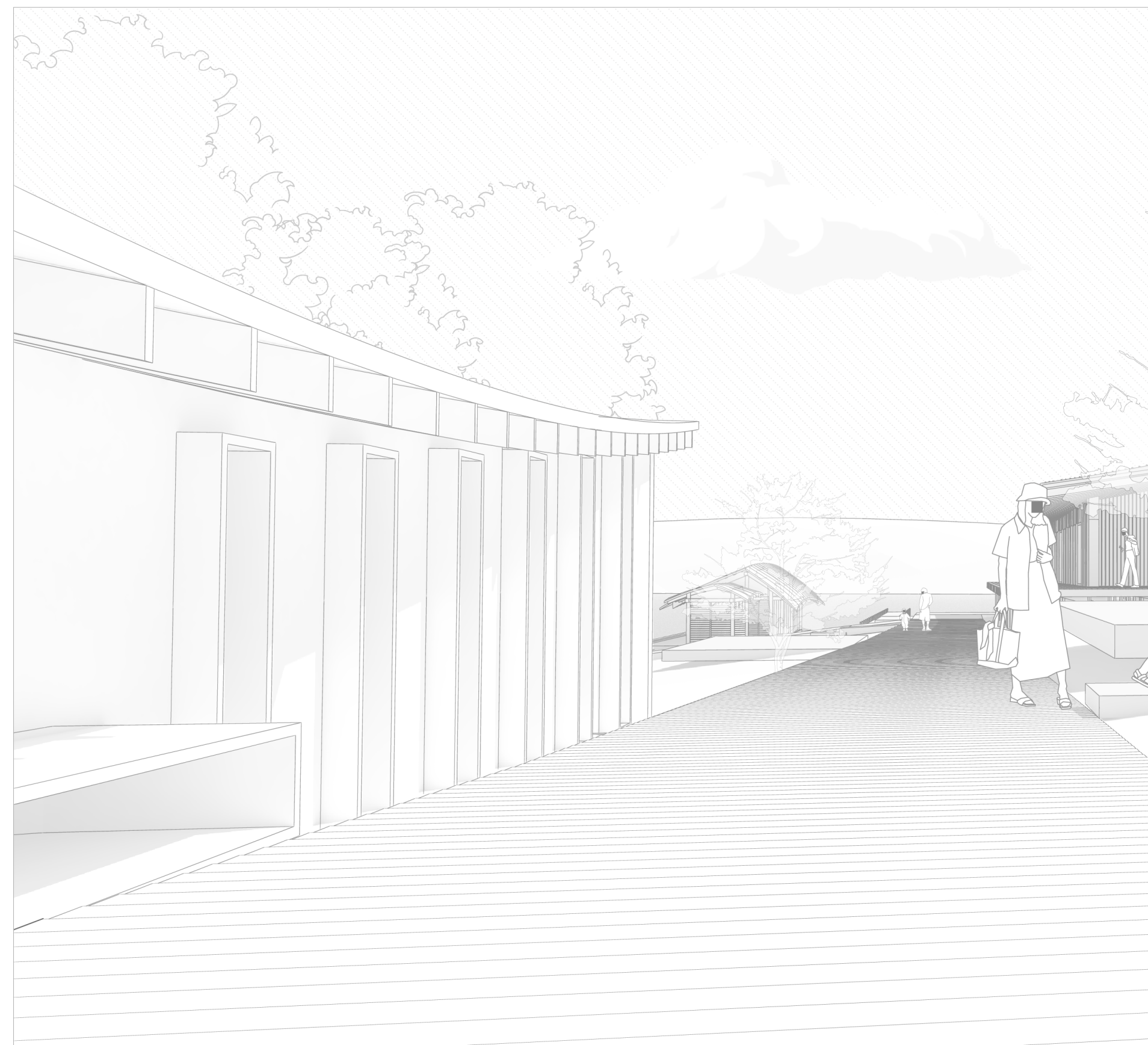

Figure 1 [ View of the retreat from the boardwalk] 


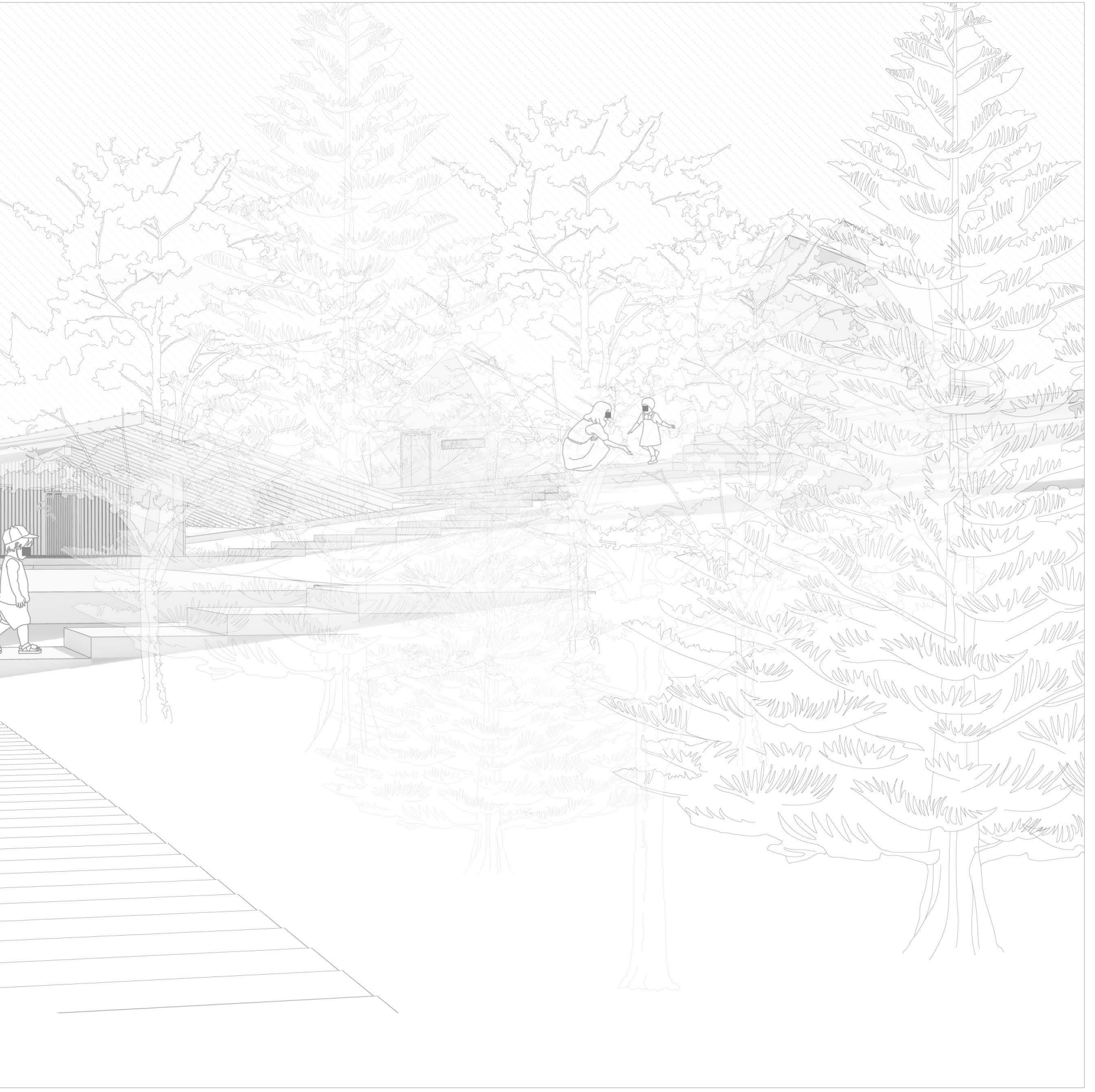


Table of Contents

ACKNOWLEDGEMENTS 2

ABSTRACT 3

REFLECTION ONE: FAMILY

1997 HANDOVER 14

\begin{tabular}{ll} 
PROTEST & 17 \\
\hline
\end{tabular}

MODERN BACKGROUND AND CURRENT EVENTS 24

REFLECTIONTWO: IDENTITY

ACADEMIC FREEDOM $\quad 32$

\begin{tabular}{ll} 
SCHOLARS & 37 \\
\hline
\end{tabular}

CONTEXT AND DESIGN INTENT

THE PROJECT

\begin{tabular}{ll} 
CONCLUSION & 74 \\
\hline
\end{tabular}

NOTES AND BIBLIOGRAPHY 76 


\section{LIST OF IMAGES}

Figure 1 [ View of the project from the boardwalk ]

Figure 2 [ family portrait ]

Figure 3 [ Photo of the handover of Hong Kong featuring the flag for the HKSAR on the far left ]

Figure 4 [ Tens of thousands gather at Admiralty to protest the 16 Extradition Bill ]

Figure 5 [ Protestors fill up Victoria Park, Causeway Bay in protest of the Extradition Bill ]

Figure 6 [ Tens of thousands of people march on government HQ in protest of educational reform]

Figure 7 [ A protestor holds an umbrella in defiance outside government HQ at Admiralty ]

Figure 8 [ Confrontation between protestors and police near PolyU]

Figure 9 [ Customers line up outside an eatery by a fire started by the protestors in Mong Kok ]

Figure 10 [ Police firing tear gas at protestros attempting to reach the cordon near PolyU ]

Figure 11 [ Family portrait with mother and father ]

Figure $12[\mathrm{ONE}$ ] 
$\begin{array}{lr}\text { Figure } 13 \text { [ TWO ] } & 40\end{array}$

Figure 14 [ THREE and FAMILY ] 41

Figure 15 [ FOUR ] 42

Figure 16 [ FIVE and FAMILY] 43

$\begin{array}{ll}\text { Figure } 17 \text { [ SIX ] } & 44\end{array}$

Figure 18 [ Photos of Haystack Mountain on the left and 46

Yaddo on the right]

Figure 19 [ View of the retreat from out on Lac Meech ] 47

Figure 20 [ Photo looking out onto Lake Meech ] 49

Figure 21 [ Photo at a Gatineau Park lookout point ] 49

Figure 22 [ Map of Gatineau Park and the site's relation to 51

Gatineau and Ottawa ]

Figure 23 [ Entrance to the project, cutting through a line of 52 trees]

Figure 24 [ Site Plan drawing ] 53

Figure 25 [ Scholars preparing lunch together in the 54 meetinghouse ]

Figure 26 [ Elevation drawing of the meetinghouse ] 55 


\section{LIST OF IMAGES}

Figure 27 [ Plan drawings of the meetinghouse ]

56

Figure 28[ Section drawing cutting through the meetinghouse ]

58

Figure 29 [ Elevation drawing of the cabins ]

Figure 30 [ Scholar resting in their cabin, reading a book before bed ]

Figure 31 [ Plan drawings of the cabins ]

Figure 32 [ Elevation drawing of the library ]

Figure 33 [ Section drawing of the library ]

62

Figure 34 [ Plan drawing of the library ]

Figure 35 [ Section drawing of the library (study carrels) ]

Figure 36 [ Scholars preparing for a day trip on the water ]

Figure 37 [ Plan drawings of the Equipment Shed ]

Figure 38 [ Section drawing of the Equipment Shed ]

Figure 39 [ Plan drawing of the Contemplation Space ]

69

Figure 40 [ Section drawing of the Contemplation Space]

Figure 41 [ Elevation drawing of the Contemplation Space ] 
Figure 42 [View across the project from the boardwalk]

Figure 43 [ Scholars entering the Meetinghouse ] 


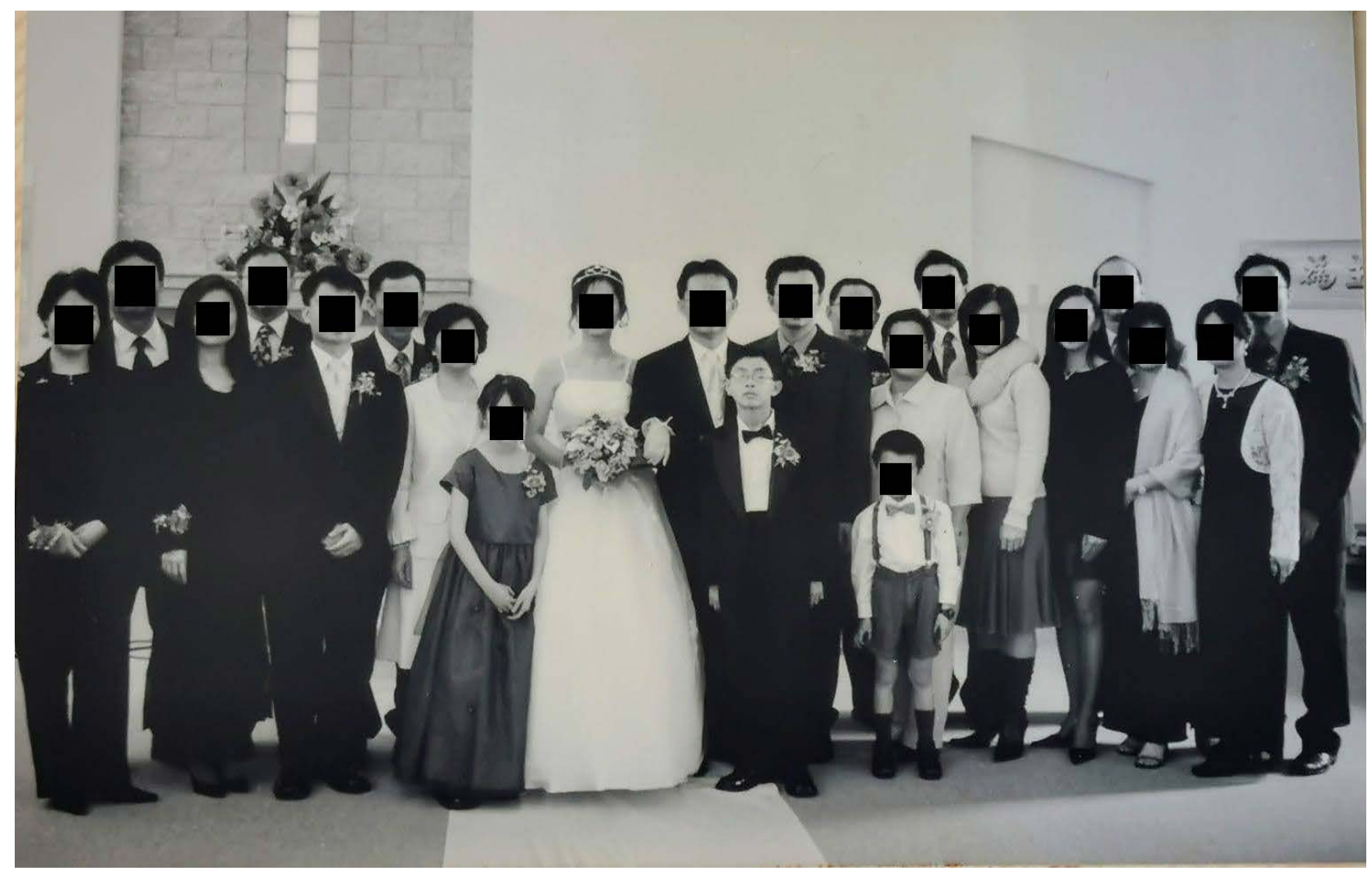

Figure 2 [ $\square$ family portrait ] 


\section{REFLECTION ONE: FAMILY}

My father is the youngest of eight siblings, my mother is the third of six. Both come from large extended families in Kwun Tong, the most densely populated of Hong Kong's eighteen districts. My parents grew up in the 1970s and 1980s before they immigrated to Canada in 1994 where they got married and I was born.

I have lived in Canada all my life but have had strong ties to family that has decided to remain in Hong Kong. My parents and I have gone to visit them nearly every year for as long I can remember with my most recent trip taking place last year amidst the 2019 protests. This project emerges from my relationships with the people I have known and loved all my life, and our shared love of the place that we come from.

Moving forward, any names, faces, opinions, and personal backgrounds of those involved or mentioned in the project have been hidden to protect their identities and privacy, as well as to shield my loved ones from the very persecution that the project stands against. 


\section{HANDOVER}

Hong Kong's history as a British colony begins after China's defeat in the first Opium War in $1842^{1}$, followed by the ceding of Kowloon in 1860 and finally the leasing of the New Territories in 1898 with a promise to return it to China after 99 years. This fortified British occupation and control in the area. Under British rule, Hong Kong experienced rapid development in its economic system and reaped the benefits of a vastly different political and economic system than the rest of China, flourishing as a region and becoming the center of commercial and financial services as the old world's gateway to the East. ${ }^{2}$

In 1979, negotiations began between Britain and the People's Republic of China (PRC) over sovereignty of the Hong Kong Peninsula. Throughout discussions between the two countries, it became clear that China would not accept any future involvement of the British in regards to governance of the Hong Kong Peninsula and that the PRC would be willing to take back control of Hong Kong by force if an agreement could not be reached. Discussing alternatives to direct British involvement, both parties agreed to Hong Kong becoming a special region within China, retaining a high degree of economic and administrative autonomy and self-governance under Chinese sovereignty and maintaining their way of life developed under British rule.

In 1984, the Sino-British Joint Declaration was signed by the chairman of the PRC and the UK, marking the return of Hong Kong Island, the Kowloon Peninsula and the New Territories to China, ending 156 years of British colonial rule. 
The declaration outlined the conditions of the handover and China's agreement to follow the "one country, two systems" principle which would be stipulated in the Hong Kong Basic Law. Acting as its own mini-constitution, the Hong Kong Basic Law guarantees Hong Kong a high degree of autonomy and maintains its own legislative and judicial branches. It also requires that the Chinese political system and its policies be kept out of Hong Kong with its democratic way of life remaining for 50 years after the handover, leaving Hong Kong unchanged until the year 2047. ${ }^{3}$

This also marks the establishment of the Hong Kong Special Administrative Region (HKSAR).

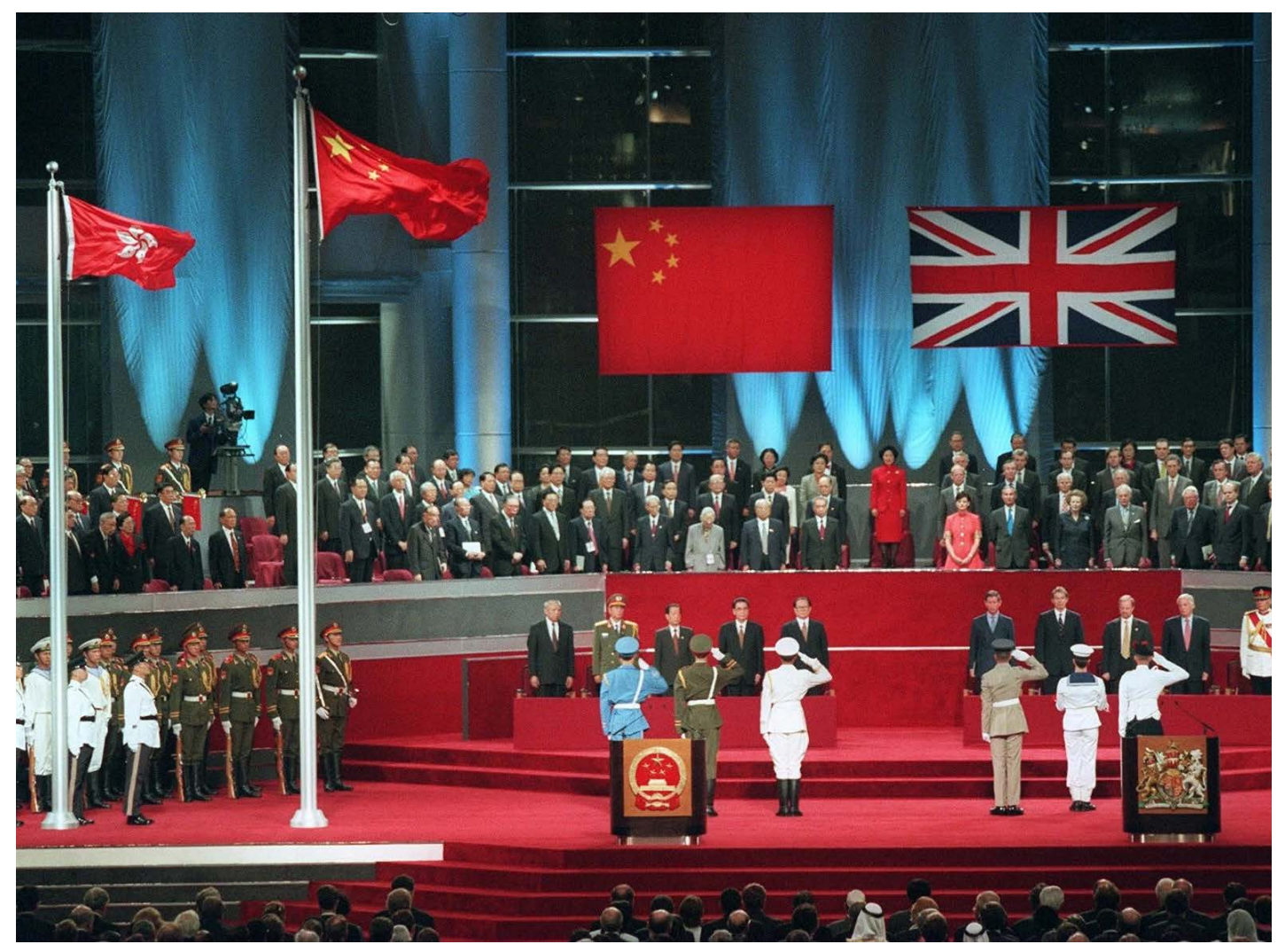

Figure 3 [ Photo of the handover of Hong Kong featuring the flag for the HKSAR on the far left ] 
Figure 4

[ Tens of thousands gather at Admiralty to protest the Extradition Bill ]

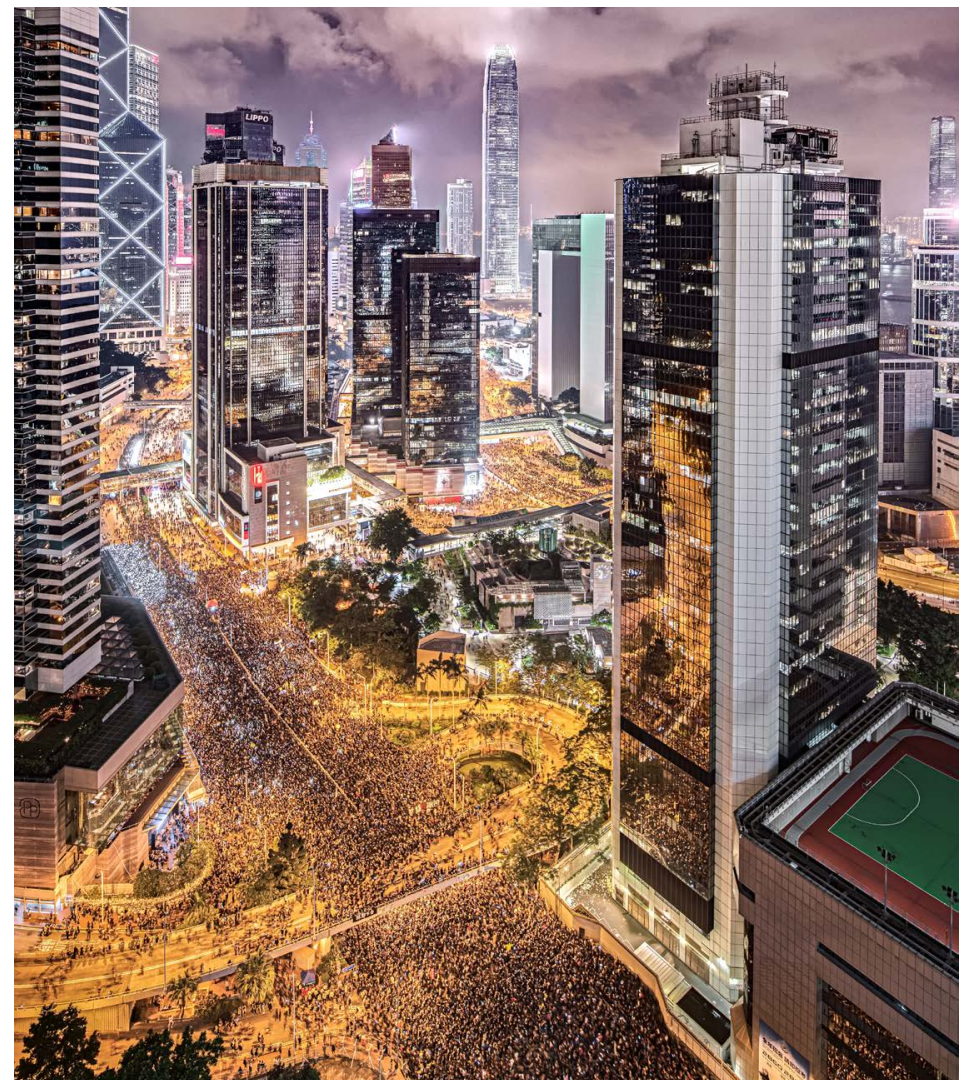

Figure 5

[ Protestors fill up Victoria Park, Causeway Bay in protest of the Extradition Bill ]

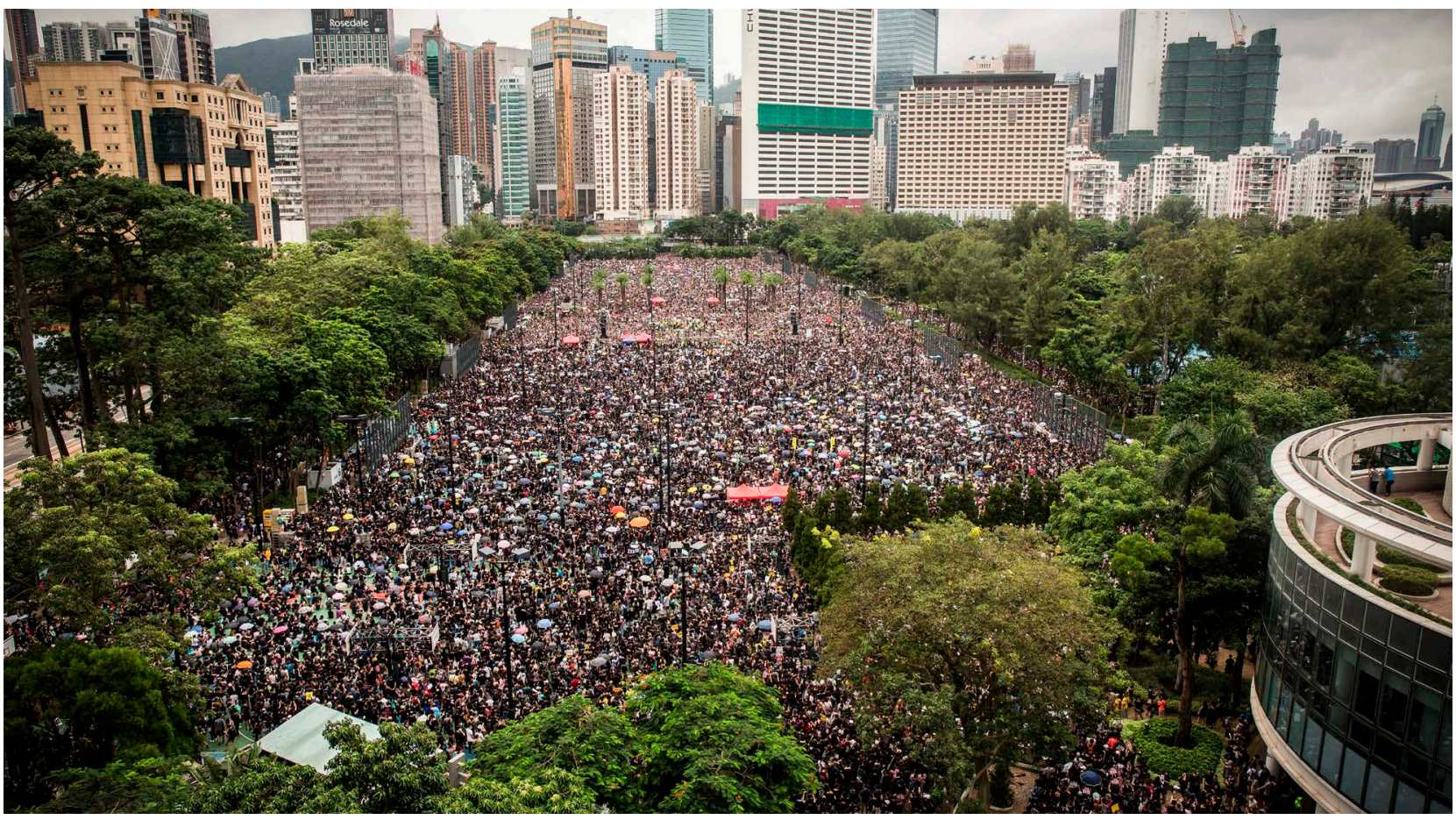




\section{PROTEST}

Hong Kong and its people have a strong history of speaking out as a united front, starting with protests against the massacre that took place in Tiananmen Square in 1989 and the vigils and ceremonies that take place every year since. Over $89 \%$ of its citizens identify as "Hong Kongers", not as "Chinese", a number that has been steadily rising since the 2000s, spiking amongst HK youth as the younger generation reaches the peak of its split-identity syndrome. ${ }^{4}$

While freedom of speech and freedom of assembly are protected as constitutional rights as outlined in the Basic Law, Hong Kong has yet to establish universal suffrage with only a third of its legislative council to be elected by proportional representation. The remaining two thirds are appointed through a "complex, multilayered system", specifically to lower the number of pro-democracy seats, keeping the council stocked with pro-Beijing representatives. ${ }^{5}$

The CCP's empty promises of true democratic elections and their continued denial of electoral reform are what eventually sparked mass protests throughout the region in 2014. Unable to elect their own representatives, the people of Hong Kong have found public protests and demonstrations to be the only ways for them to make their voice heard. 
In 2003 the CCP attempts to introduce Article 23, a piece of anti-subversion legislation that prohibited treason, secession, sedition and subversion against the Chinese government, and were met with strong opposition, drawing over 500,000 people out on July 1 st in protest. ${ }^{6}$ Although the groundwork for the bill was outlined in the Hong Kong Basic Law, the people of Hong Kong were outraged that the Chinese government would attempt to introduce changes to the legislature of Hong Kong, a mere 6 years into their 50-year moratorium on legislative changes, and were suspicious of the vagueness of its terms. The actions of the protestors drew international ${ }^{7}$ media attention and forced the local Hong Kong government to reverse its support for the bill. ${ }^{8}$

2012

The CCP attempt to amend the curriculum of the HK school system to include China's history, culture, and national identity. These changes were met with resistance from tens of thousands of Hong Kongers attending protests against the changes on July 29. Students, parents, and teachers gathered to protest what they believed to be an attempt to indoctrinate the youth of Hong Kong. These protests led to the founding of the group Scholarism led by Joshua Wong who was only 15 years old at the time. ${ }^{9}$ C.Y. Leung, Chief Executive of Hong Kong, announced that he would give individual schools the choice to implement the new curriculum, effectively rendering the bill dead. 


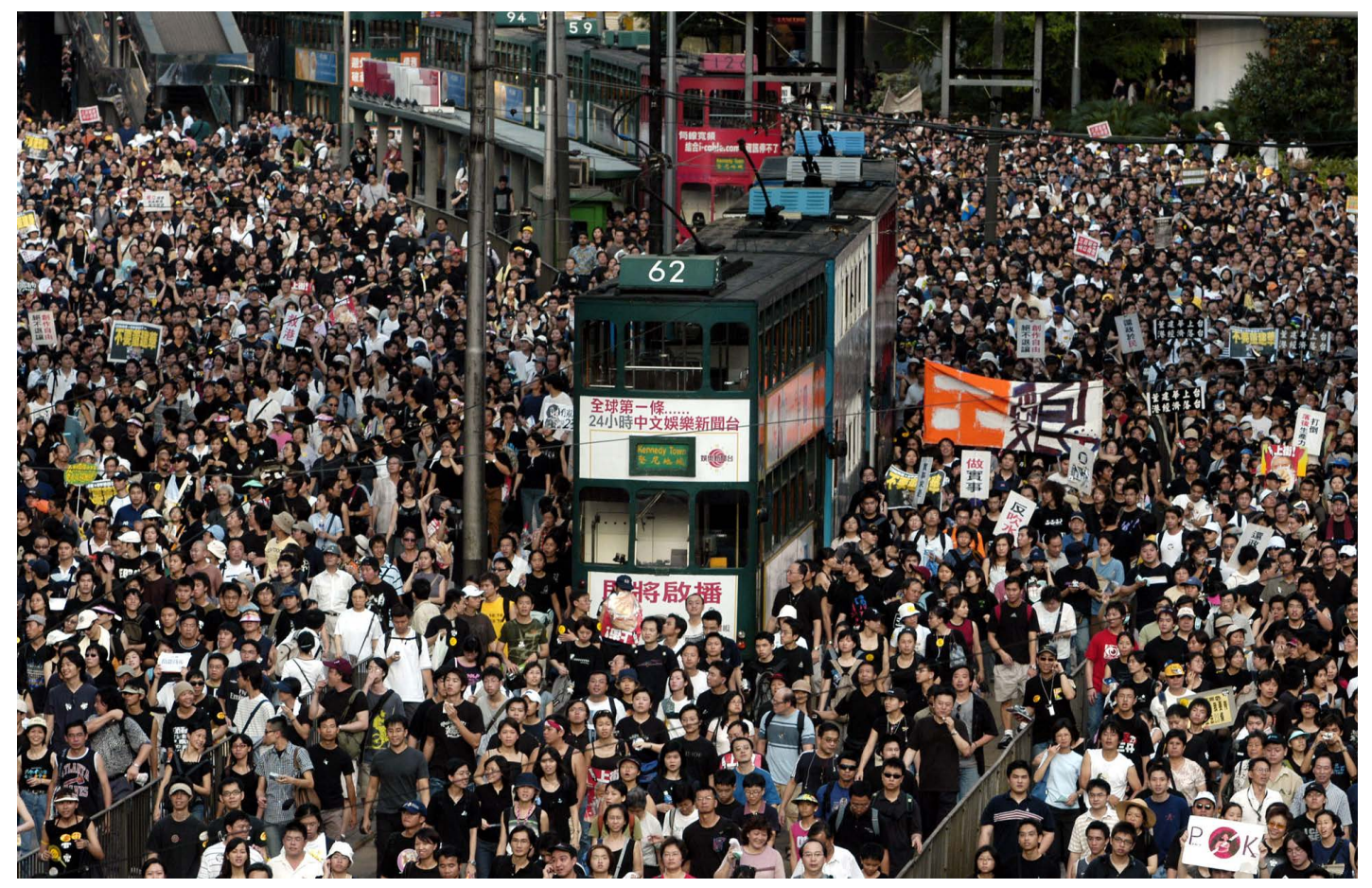

Figure 6 [ Tens of thousands of people march on government HQ in protest of educational reform]

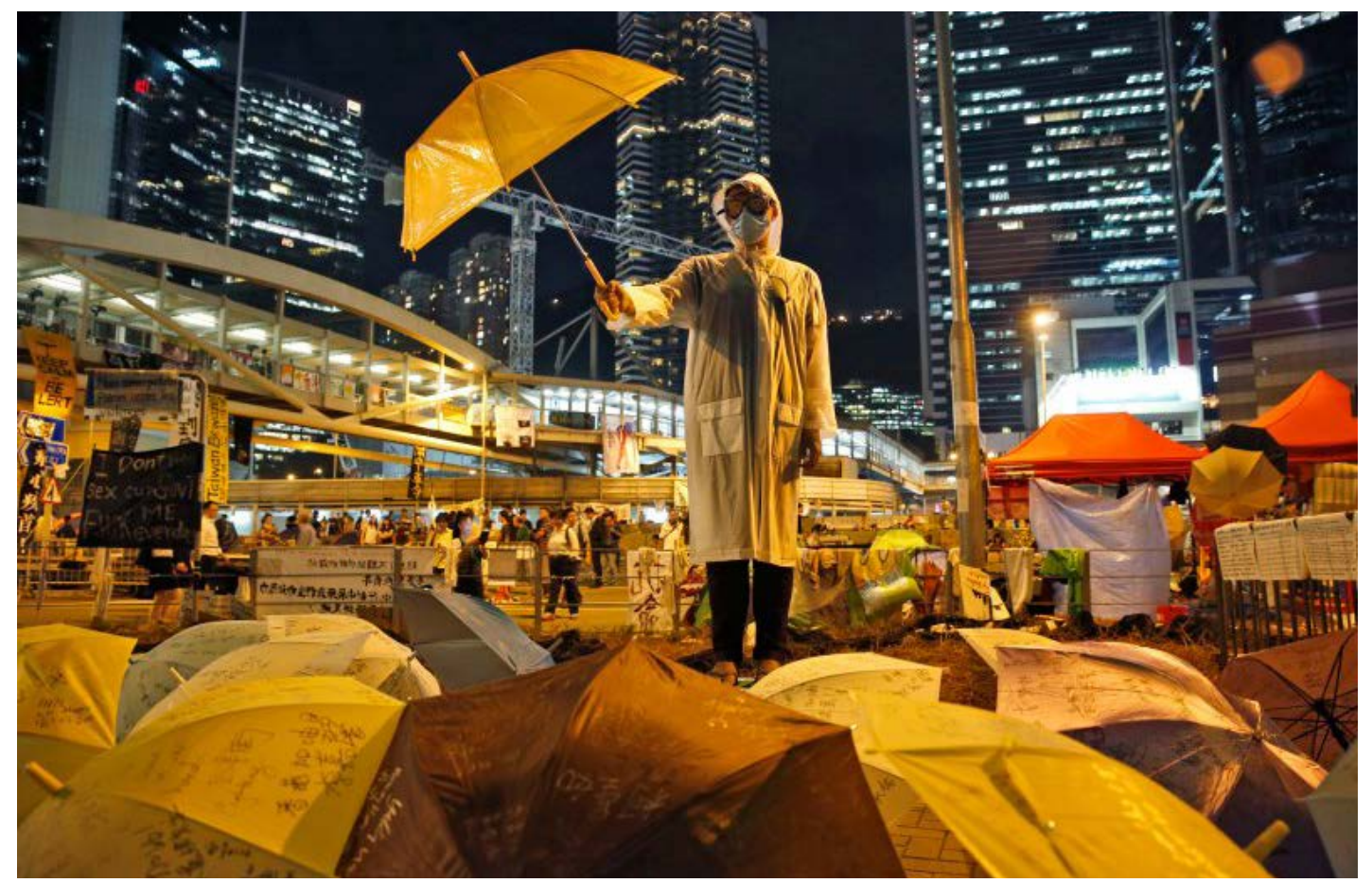

Figure 7 [ A protestor holds an umbrella in defiance outside government HQ at Admiralty ] 
The CCP put forward proposals for electoral reform with the stipulation that all candidates be pre-screened before being allowed to partake in the election. Effectively, it would remove the democratic right to select their leader and intense opposition from the city's residents gathered on the streets in protest. The Hong Kong Federation of Students and Scholarism began protesting outside government headquarters, eventually spilling over to several major city intersections including the city's central business district, "Central". Groups of peaceful demonstrations throughout the city were dispersed with tear gas, inspiring tens of citizens to join the protests, reaching 80,000 strong, up to $100,000 .{ }^{10}$ The police responded with more tear gas, firing over 87 canisters at the crowd. ${ }^{11}$

As an act of defiance, the public sparking a new movement, the "Umbrella Revolution", and continued to occupy government headquarters and attended the National Day Flag raising ceremony, opening up bright yellow umbrellas and turning away as the flag was raised to show their discontent. ${ }^{12}$ Student-leader Joshua Wong, now 17 years of age, had become the face of the movement and was later arrested, along with seventy-seven other protestors as the movement came to an end after almost two months of protests without any concessions from Beijing. 
Named after the popular street snack, the "Fishball Revolution" was a response to authorities attempting to crackdown on unlicensed food vendors in the Mong Kok district. Around 300 people took to the streets, fighting against what they perceived as a direct attack on Hong Kong tradition and way of life. The protests turned violent after warning shots from the police, a first at Hong Kong protests, and the crowds retaliated, throwing bricks and petrol bombs at authorities. ${ }^{13}$

2019

An extradition bill outlining changes to the constitution to allow the government of Hong Kong to consider requests from any country for extradition, even countries that it does not have a treaty with currently (including mainland China), was introduced in April. This prompted the latest series of protests as the people of Hong Kong feared for their judicial independence and encroachment upon the autonomy granted by the "one country, two systems" agreement. With 28 years left in the supposed agreement, this put many people at risk in Hong Kong for conducting work related to the mainland as they could now be sent to face arbitrary detention, unfair trial, and torture under China's judicial system.

As clashes between protestors and the police escalated, sustained use of violence by the police prompted hundreds of thousands of citizens to join the protests, peaking at 1.7 million people at a peaceful rally in Victoria Park and the bill was eventually withdrawn. ${ }^{14}$ However, protests continued and prompted police to carry out raids on higher education institutions, beginning with a warrantless search of the Chinese University of Hong Kong where five students were detained for putting up protest related posters. 
Further escalating the situation, the police laid siege to the University of Hong Kong, Hong Kong Polytechnic University and the Chinese University of Hong Kong as well as several other institutions. Police made efforts to remove students and other "dissidents" who were occupying the campus, a harrowing reflection of the CCP's attempts to remove student protestors at Tiananmen Square 30 years ago. Thousands of canisters of tear gas, rubber bullets, bean bag rounds, and sponge grenades were fired indiscriminately at protestors, medics, and journalists. Over the next eleven days, protestors were trapped inside the campus before the police stormed the campus on November 28, removing and arresting anyone still remaining. ${ }^{15}$

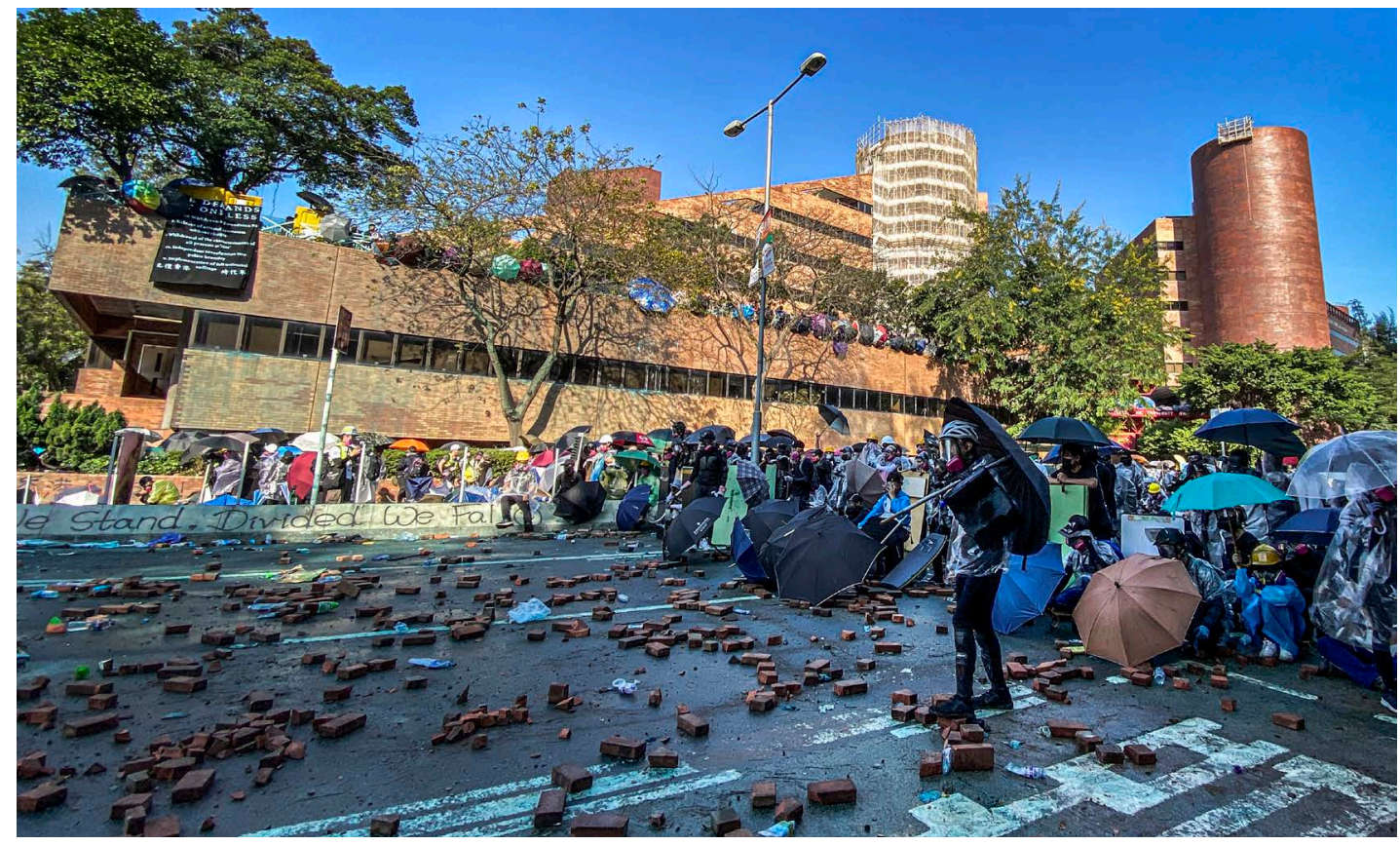

Figure 8 [ Confrontation between protestors and police near PolyU] 


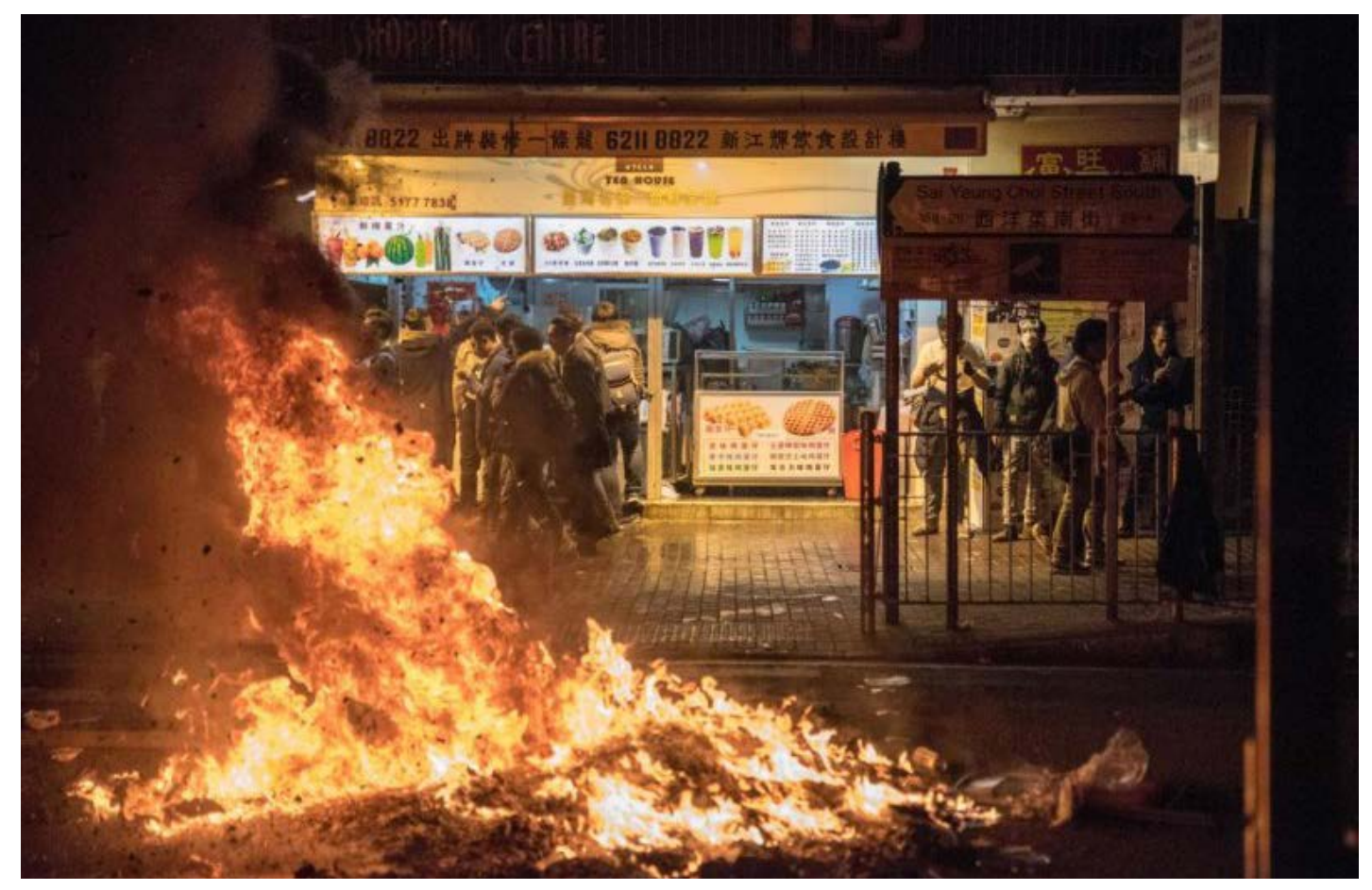

Figure 9 [ Customers line up outside an eatery by a fire started by the protestors in Mong Kok ]

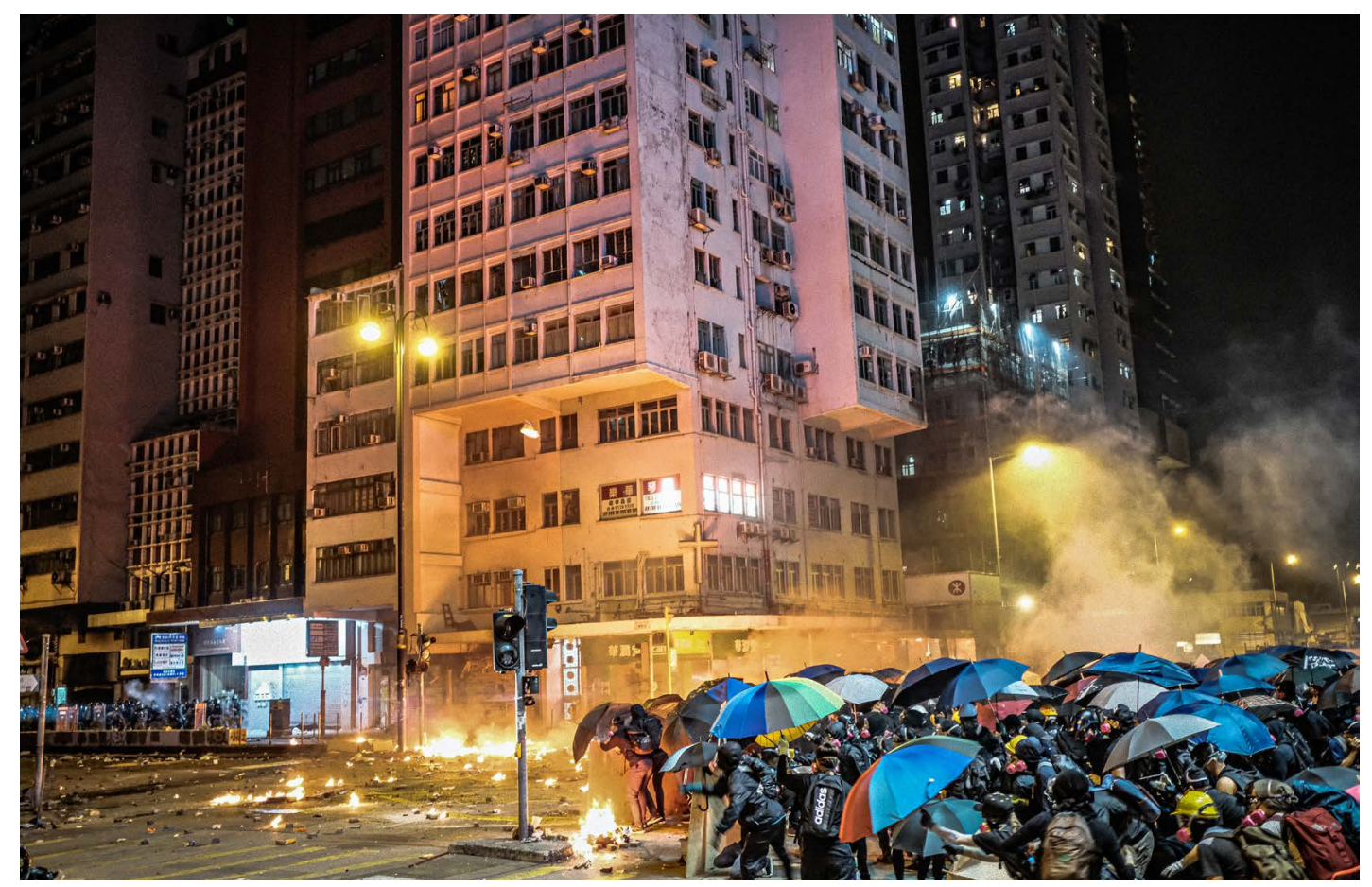

Figure 10 [ Police firing tear gas at protestros attempting to reach the cordon near PolyU ] 


\section{MODERN BACKGROUND AND CURRENT EVENTS}

The following timeline consists of a compilation of journalistic articles detailing the everyday struggle and relentless onslaught against civil and human rights within Hong Kong.

January 10

Canada calls Hong Kong mass arrests an 'assault on representative democracy'16

Canada’s Foreign Affairs Minister François-Philippe Champagne says the mass arrest of opposition politicians and activists in Hong Kong this week is an "assault on representative democracy" in the former British colony and offers proof that a sweeping new security law is being used as a cudgel against "peaceful political opposition and grassroots electoral politics.”

Hong Kong police arrested 53 people in dawn raids on democracy activists Wednesday in the biggest crackdown since China last June imposed a security law which opponents say is aimed at quashing dissent.

"These arrests fundamentally contradict the civil and political rights guaranteed to the people of Hong Kong under the Basic Law,” Mr. Champagne said.

He said the arrests also represent a further breach of the liberties pledged by Beijing in 
the Sino-British Joint Declaration that was to govern affairs in Hong Kong for 50 years after the handover.

\section{January 13}

China in darkest period for human rights since Tiananmen, says Human Rights Watch $^{17}$

China is in the midst of its darkest period for human rights since the Tiananmen Square massacre, Human Rights Watch has said in its annual report.

Worsening persecutions of ethnic minorities in Xinjiang, Inner Mongolia and Tibet, targeting of whistleblowers, the crackdown on Hong Kong and attempts to cover up the coronavirus outbreak were all part of the deteriorating situation under President Xi Jinping, the organization said.

"This has been the darkest period for human rights in China since the 1989 massacre that ended the Tiananmen Square democracy movement," the report on worldwide human rights abuses said.

\section{February 4}

Hong Kong pro-democracy movement nominated for Nobel peace prize by US lawmakers ${ }^{18}$

US lawmakers have nominated Hong Kong's pro-democracy movement for the Nobel peace prize, calling the campaigners a global inspiration in the face of a crackdown by Beijing. 
Given Hong Kong has a population of 7.5 million, it amounts to "one of the largest mass protests in history", said the letter, led by Republican senator Marco Rubio and Democratic representative Jim McGovern, co-chairs of the congressional-executive commission on China which assesses human rights.

"This prize would honour their bravery and determination that have inspired the world," they wrote. "We hope that the Nobel committee will continue to shine a light on those struggling for peace and human rights in China and we believe the prodemocracy movement in Hong Kong is deserving of recognition this year."

\section{February 5}

\section{'Let's learn about national security': Hong Kong rewrites school rules ${ }^{19}$}

Hong Kong students as young as six will be taught about the national security law under a dramatic overhaul of the education curriculum.

Notices sent out on Thursday require schools to prevent participation in political activities, increase monitoring of employees and teaching materials, remove books and flyers deemed to endanger national security, and to report to authorities if necessary.

The animation - entitled Let's Learn About National Security and accompanied by upbeat music and quirky sound effects - appears aimed at young children but uses technical and legal terms.

The changes to the school curriculum are the latest move by the government to crack down on dissent, and increase control of the political leanings of Hongkongers beyond 
activists and opposition figures. Last year the city's leader, Carrie Lam, blamed the liberal studies curriculum for fueling the 2019 pro-democracy protests, and vowed to overhaul the education system.

\section{February 28}

47 key activists have been charged with subversion and face life if convicted ${ }^{20}$

The European Union's office in Hong Kong said the charges made clear that "legitimate political pluralism will no longer be tolerated in Hong Kong" and called for the immediate release of the detainees. Both Human Rights Watch and Amnesty International accused authorities of using the national security law to silence critics, called for all charges to be dropped.

Those arrested include young campaigners, activists, and local councilors, as well as established politicians such as Claudia Mo, Eddie Chu Hoi-dick and Ray Chan. The activist and former politician Joshua Wong is already in jail, serving 13 months on protest-related charges.

\section{March 11}

\section{China moves to tighten control over Hong Kong's electoral system ${ }^{21}$}

China's ceremonial legislature on Thursday endorsed the Communist Party's latest move to tighten control over Hong Kong by reducing the role of its public in picking the region's leaders. The National People’s Congress voted 2,895-0, with one abstention, to endorse changes that would give a pro-Beijing committee power to appoint more of Hong Kong's lawmakers, reducing the number elected by the public. Delegates 
routinely endorse party plans by unanimous vote or overwhelming majorities.

The mainland government has rejected complaints that it is eroding Hong Kong's autonomy and says the changes are necessary to protect the region's stability.

\section{March 19}

\section{China NPC: Beijing to overhaul Hong Kong electoral system ${ }^{22}$}

NPC vice-chairman Wang Chen announced to the NPC that changes were needed as "the rioting and turbulence that occurred in Hong Kong society reveals that the existing electoral system has clear loopholes and deficiencies". ${ }^{23} \mathrm{He}$ said "risks in the system" needed to be removed to ensure "patriots" were in charge.

\section{March 21}

\section{Hong Kong's Arts scene shudders as Beijing draws cultural red line ${ }^{24}$}

After successfully muzzling Hong Kong's democracy protests and opposition, Beijing's loyalists have warned art institutions about their collections as they seek to impose mainland-style orthodoxy on culture and purge the city of dissent.

Newly built on Hong Kong's Victoria Harbour, M+ Museum aims to rival western contemporary heavyweights like London's Tate Modern and New York's MoMA.

The 60,000 square-metre venue is finally set to open later this year after multiple delays. But it has already found itself in hot water. 
Earlier this week a group of prominent pro-Beijing local politicians accused the museum of breaching a sweeping national security law that China imposed on Hong Kong last year in response to 2019's democracy protests.

Carrie Lam, Chief Executive of Hong Kong, replied that Hong Kong "respects the freedom of cultural and artistic expression”.

But she warned authorities would be on "full alert" for any breaches of the security law, adding that the red line "is clearly recognisable" for anyone hosting exhibitions. The exchange sent a new shudder through the arts scene in a city struggling to hold onto its reputation as an international cultural gateway to China unhindered from the authoritarian mainland's controls. 


\section{REFLECTION TWO: IDENTITY}

Growing up I have always considered myself Canadian first and foremost. Although Hong Kong and China have never cemented themselves within my personal identity, they are an undeniable part of my path and my family's history. They are where I have come from, but are no longer truly a part of who I am now.

I have watched my father's opinion of his origins change and warp over the years. He would tell me story after story, nostalgic memories from his childhood that he remembers fondly. Tales of sailing in the bay with his friends, trips to the mainland with his brothers and sisters, camping out in the forests, and walking the trails that meandered through the island's undergrowth. He would talk about meeting my mother, the time they spent together, and having to spend months away from her as he headed off to teacher's college.

When we went to visit Hong Kong, we would take long walks around the city as he pointed out buildings and roads, businesses and restaurants that had been around since he was a teenager himself. He would tell me how his city had kept changing and shifting, yet had kept the core elements that made Hong Kong such a vibrant, wonderful place. I remember him telling me how proud he was to be Chinese as we watched the opening ceremony of the Beijing Olympics, welling up with patriotic pride as a new China showed up to the world stage. 
In recent years, this slowly transformed into fits of disgust and outrage as he saw his childhood home take a turn for the worse. He watched as his city descended into chaos and conflict, looked on in horror as the government cracked down on dissent and protest, tightening its grip and slowly choking the life from its citizens. Hong Kong could no longer hold on to its unique identity as oppression from China grew. A real turning point was when he realized many of those protesting in Hong Kong were students and young adults who were fighting for their rights and freedoms, beaten and arrested for defending what they believed in. He wondered out loud one day during dinner, whether I would have been one of them.

I wonder about that myself.

Would I have been out there on the front lines, dousing tear gas canisters? Would I have been the one throwing them back in defiance?

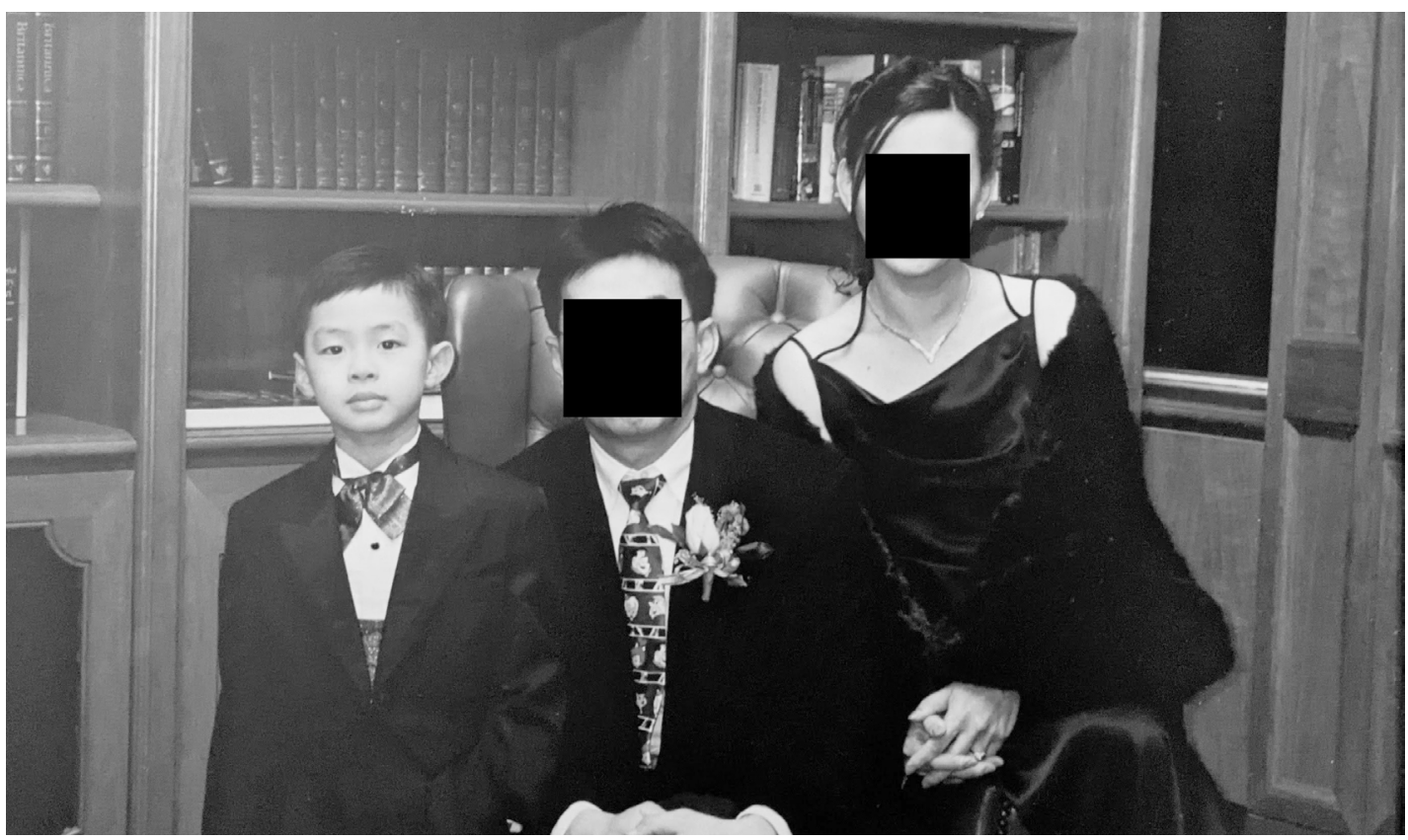

Figure 11 [ Family portrait with mother and father ] 


\section{ACADEMIC FREEDOM}

Joshua Wong is my age and he is sitting in jail for the third time for organizing protests and defend his human rights and that of his peers.

The assault on his freedom of speech and expression has resulted in the confinement of his physical freedom. No one should have to imagine themselves in a situation where this is possible. However, this insidious grip on his personal freedom started from attacks on his academic freedoms and of the youth of Hong Kong, beginning in the 2000s. ${ }^{25}$

\section{What is Academic Freedom?}

Academic freedom has been defined by UNESCO as the freedom of academics:

- $\quad$ to teach and discuss

- to carry out research and publish the results and make them known

- to freely express opinions about the academic institution or system in which one works

- to participate in professional or representative academic bodies

- $\quad$ not to be censored ${ }^{26}$

The principle of academic freedom comes from freedom of thought, one of the 30 basic human rights according to the UN. ${ }^{27}$ Academic freedom includes the freedom to teach and the freedom to learn, both fundamental to the proper functioning of higher education, critical thinking, and the development of new ideas. It is through that 
process of producing and consuming knowledge that higher education institutions and the professionals who work within them teach, learn and innovate. ${ }^{28}$

It protects scholars' rights to pursue whatever fields of study they find to be most worth their time, but also the rights of colleagues and peers to debate and discuss each other's work; it protects their right to argue its faults and ensures that research is open and transparent, assuring that research can be discussed and proven wrong, or right. It actively discourages and fights against misinformation or biased research and rebuffs irresponsible or indefensible opinions.

It benefits all of society through the creation of new knowledge, facilitates innovation and pushes society forwards through political, economic, social, and technological progress. Academic freedom serves the common good, and threats to it are threats to an individual's basic human rights as well as the basic democratic principles of freedom, equity, fairness and justice. ${ }^{29}$ 


\section{"Protecting scholars and the freedom to think, question and share ideas."}

Scholars at Risk (SAR) is an international network of higher education institutions and individuals dedicated to protecting threatened scholars, preventing attacks on higher education, and promoting academic freedom and related values worldwide. ${ }^{30}$

SAR protects scholars suffering grave threats to their lives, liberty, and well-being. Using a two-pronged approach, (1) by arranging temporary research and teaching positions at institutions within the SAR network and (2) by providing advisory and referral services to support their wellbeing. Scholars are often housed within a department at the university based on their field of study and are given a chance to teach or conduct research during their term in the program. The department is responsible for mentoring the scholar and helping them build connections and contacts within the academic community.

A section of SAR known as Scholar Care works more closely with scholars and assists them with a more personal focus on helping them transition to Canada. They are a point of contact for scholars, as many arrive in Canada with almost no prior relations or support network, and help them with personal needs, such as familiarizing them with the community and the neighborhood that they have chosen to reside in. Scholar Care meets with the scholars on a monthly basis, keeping in touch and monitoring their wellbeing and helping them adapt to life in Canada. 
I have chosen to work with SAR in hopes to bring awareness to the organization and their initiatives to help scholars under threat and in need. At its core, SAR works to protect academic freedom and human rights and by rallying an international community of scholars and educators to create a support structure. Academics and researchers are often the first to be targeted by governments looking to achieve total control, with activists and journalists close behind, and SAR looks to protect the creation of knowledge and its preservation for the good of humanity. SAR boasts an impressive and far-reaching web and support network with branches at universities all over Ontario and Canada. ${ }^{31}$

Currently SAR has branches at twenty universities across Canada, the closest outside of Carleton being at the University of Ottawa and McGill University.

\section{SAR Member Directory}

$\begin{array}{ll}\text { Canadian Association of University Teachers } & \text { Université du Québec à Montréal } \\ \text { Carleton University } & \text { The University of Alberta } \\ \text { George Brown College } & \text { University of Guelph } \\ \text { McGill University } & \text { University of Lethbridge } \\ \text { McMaster University } & \text { University of British Columbia } \\ \text { Memorial University of Newfoundland } & \text { University of Ottawa } \\ \text { Mount Royal University } & \text { University of Toronto } \\ \text { Queen's University } & \text { University of Victoria } \\ \text { St Mary's University } & \text { Vancouver Island University } \\ \text { Simon Fraser University } & \text { Western University } \\ \text { Trent University } & \text { York University }\end{array}$


SAR has documented 126 separate incidents of attacks on higher education just over the last five years within Eastern Asia. ${ }^{32}$

Of the 126 incidents, 118 of these attacks took place in China and Hong Kong.

In the year 2020 there have been 14 incidents reported by SAR within China and Hong Kong. 


\section{SCHOLARS}

FFor the project, fictional scholars have been created from a composite of real-life examples of people who have been persecuted for protecting their human rights, people who have fled from their homes, fearing persecution, and the ideals and spirits of individuals who have been silenced and can no longer speak for themselves. These scholars represent the kinds of people that the project is hoping to provide a home, and a voice for.

There are six scholars, united in their fight for intellectual freedom.

They are

A Hong Kong Journalist,

A Uighur Activist,

A Chinese Lawyer,

A Hong Kong Student Activist,

A Chinese Professor, and

A Tibetan Activist 
Each scholar has a history from before they were invited to take part in the project, current activities that they are pursuing while participating in the project as well as long term goals to be fulfilled in the future whether they have remained as a part of the project or have moved on.

The portraits provided in the scholar bios have been created from scratch by digital software, recombining tens of thousands of portraits and photos taken of real people. This is to prevent the use of faces and identities within the project from affecting the lives of real people, and to protect individuals from being persecuted by mistake for bearing any similarities with the scholars featured within the project.

Photos created by generated.photos. ${ }^{33}$ 


\section{ONE \\ HONG KONG JOURNALIST}

ONE was arrested at her place of work during a police raid for investigating and reporting on police misconduct during the 2019 protests. ONE was part of a crew that created a short film compiling videos taken from the phones of protestors and bystanders, proving that the police had lied about their involvement with the protests and had misled the public about the level of force that they had used on protestors. Charged with rioting, $\mathbf{O N E}$

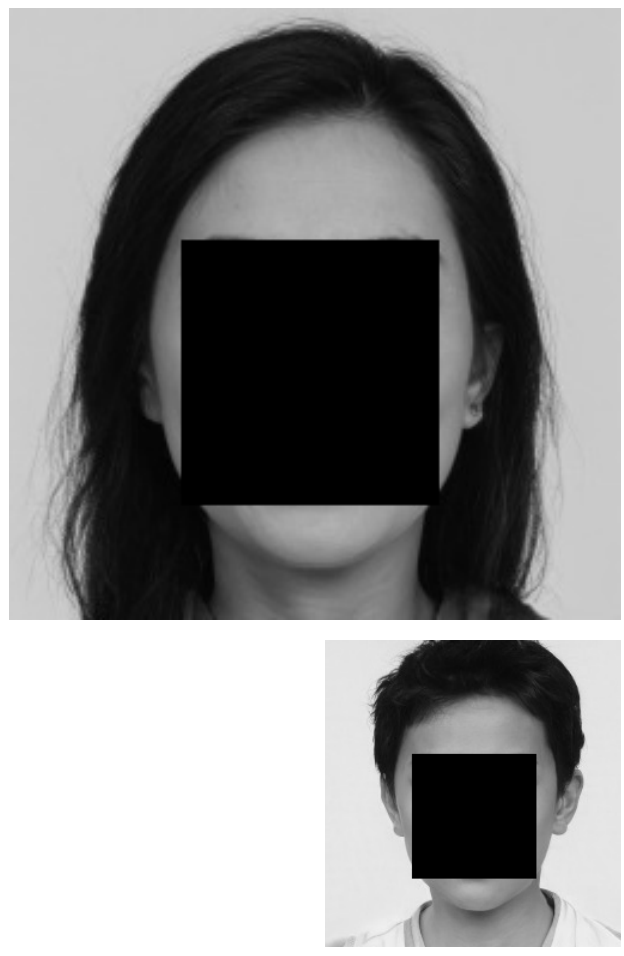

Figure $12[\mathrm{ONE}]$ was released on bail after which she fled from Hong Kong and ended up in Canada after choosing self-exile to protect her child from persecution.

ONE is currently looking to speak with political leaders and activists within Canada to help spread awareness and shine a spotlight on the issues of police brutality within Hong Kong, hoping to garner international support for the struggles and unjust treatment of Hong Kongers. She is currently writing journalistic articles on international views regarding the changing situation in Hong Kong and China and hopes to publish a series of articles, chronicling the fall of democracy in the HKSAR.

ONE has many friends and coworkers who were part of the mass arrests during the 2019 protests and is looking for ways to help them from overseas. Her husband still resides within Hong Kong and she hopes to find a way to bring him to Canada in the near future. 


\section{TWO \\ UIGHYR ACTIVIST}

TWO has been studying at Carleton for the last three years since 2018, arriving in Canada from the XUAR.

During her time at Carleton, she participated in local activist groups, speaking out against the Chinese

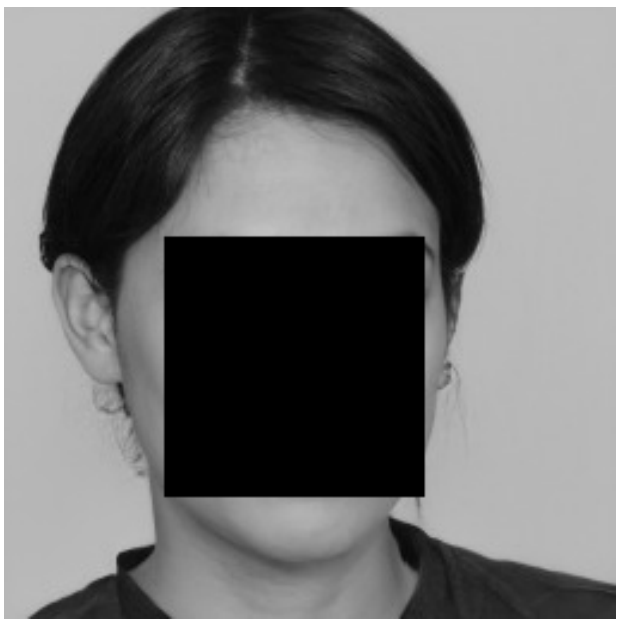

Figure 13 [ TWO ]

Communist Party on reports of genocide and the development of forced labour camps in Xinjiang. In September of 2020, she received word that her family had been taken from their homes and relocated to a forced labour camp. She has since been unable to contact any of her family in the XUAR.

TWO has received threats from Chinese government officials and has been notified that she had is charged with "inciting ethnic hatred and ethnic discrimination" and is wanted for inciting separatism abroad.

TWO has taken active roles in founding activism groups at local universities, creating branches at Carleton, University of Ottawa and McGill University to protest the actions of the CCP and demand the release of prisoners, while lobbying the Canadian government to recognize China's actions against Uighyr minorities in Xinjiang as genocide. TWO is working on garnering enough international support to establish global sanctions against the PRC for the breach of human rights and the atrocities committed to minorities and dissidents in China.

TWO holds out hope to reestablish contact with her family in Xinjiang and send them help. 


\section{THREE \\ CHINESE LAWYER}

THREE had been practicing law in China for ten years and worked at a small firm based in Beijing. After the 2019 protests in Hong Kong, he chose to represent several activists who were charged with sedition for attempting to leave the country. He was consequently raided by the police and had his offices searched. THREE's license was revoked shortly after and he was disbarred for "damaging the image of the lawyer industry". THREE believes he was targeted by the government for representing enemies of the state and made arrangements to flee the country with his wife and two children.
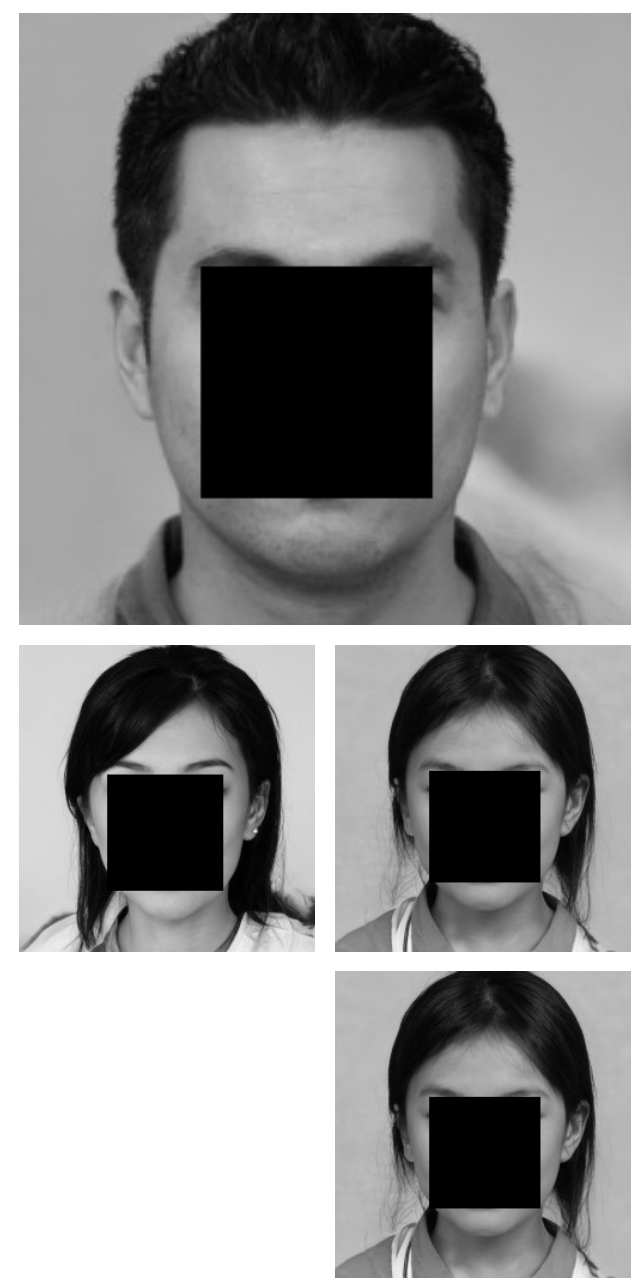

Figure 14 [ THREE and FAMILY]

Upon arriving in Canada, THREE helped set up communications with advocacy groups in Hong Kong that would help his colleagues with their cases while he was abroad. He is currently providing legal advice for refugees and political exiles that have escaped to Canada and is adapting to life in Ottawa with his family.

THREE hopes to get licensure to practice law in Canada and eventually become a professor of law and teach at a local university. 


\section{FOUR HONG KONG STUDENT ACTIVIST}

FOUR was a student at Hong Kong Polytechnic during the 2019 protests and took an active role during the demonstrations. When the school was under siege by the police, FOUR assisted with barricading doors and

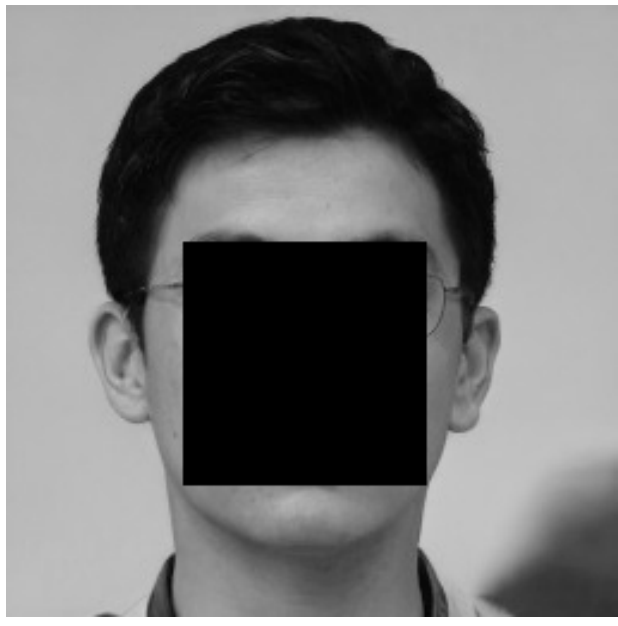

Figure 15 [ FOUR ] lobbies before helping his fellow classmates escape over the side of a cliff on the university's west edge. As the siege was ending, FOUR tended to friends and colleagues who had been wounded by the police onslaught and was arrested with twenty others for rioting. After being released on bail, FOUR decided to escape from Hong Kong, fleeing to the United Kingdom where he stayed for a couple of months before moving to Canada.

Arriving in Ottawa, FOUR enrolled at Carleton University hoping to finish his degree in Political Sciences which he began two years ago in Hong Kong. He is a member of the Carleton University branch of the Ontario United Front of Hong Kong Students (OUFHK). FOUR spends his time organising protests on campus while helping others who have fled from China and are trying to adapt to life in Canada. FOUR hopes that his work with the OUFHK will help raise awareness to the declining situation in Hong Kong. His goal is to become a Canadian citizen, allowing him to bring his parents and younger brother safely to Canada.

FOUR urges his friends and supporters to "add oil" and keep fighting for their rights in his absence. ${ }^{34}$ 


\section{FIVE \\ CHINESE PROFESSOR}

FIVE was a Professor of Economics and had been teaching in Peking University for ten years. While FIVE had been open about his political views during his tenure,

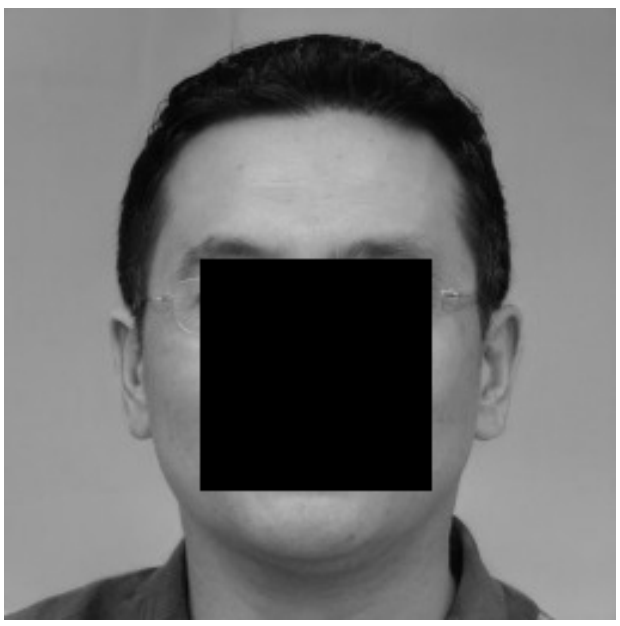
he was arrested at the start of 2020 for publishing a paper criticizing the CCP and for speaking out against the chairman and his foreign policies. He was confronted by police at his home early in the morning, where his computer and documents were seized by local authorities

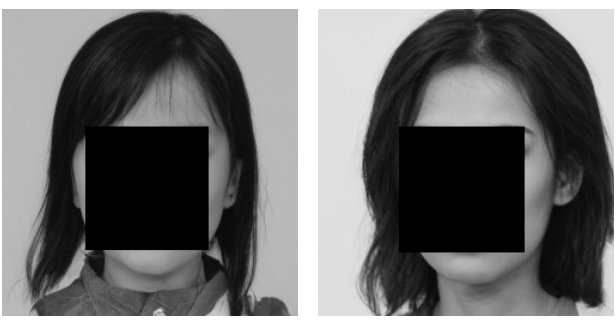

Figure 16 [ FIVE and FAMILY] and he was placed under house arrest.

FIVE reached out to SAR and its offices and they arranged for him to leave China with his wife and daughter, and he arrived in Canada later that month. He currently lives in Ottawa with his family and is a SAR sponsored scholar teaching at the University of Ottawa, housed in the Department of Economics. FIVE plans to begin writing a series of papers criticizing the CCP and their treatment of dissidents and free thinkers.

FIVE hopes to help his wife and daughter transition peacefully to life in Canada as he applies for his permanent residency. He is working on establishing an academic record within Canada, rebuilding his reputation, and developing a network of contacts at the University of Ottawa. 


\section{SIX}

\section{TIBETAN ACTIVIST AND WRITER}

SIX is a prominent member of the Tibetan Youth Congress and has a history of organizing non-violent protests and demonstrations against the CCP for their

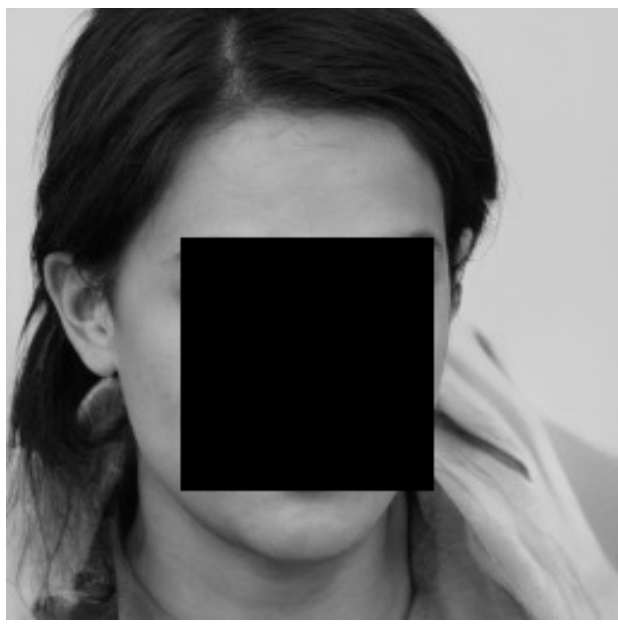

Figure 17 [SIX] occupation of Tibet in 1949 and subsequent mistreatment of its people. He was forced to leave Tibet with his parents fearing persecution by the CCP and has been residing in India since.

SIX was arrested by Indian police for organizing and attempting to stage a non-violent protest outside a venue that would be hosting a meeting between Indian diplomats and the General Secretary of the CCP, Xi Jinping. After being released on bail, SIX organized a diplomatic trip to Canada and the USA, bringing a group of Tibetan activists to appeal to the public and the governments as a cry of help for Tibetan autonomy.

SIX is currently writing two works, one an autobiography of his experiences fighting for the rights of Tibetan refugees, the other a book of poems, expressing his suffering living as a Tibetan refugee, and the struggle of living under continual persecution by the CCP. SIX decided to pause his diplomatic trip to the USA. He instead, will stay in Ottawa to organize local protests and demonstrations to raise awareness of the situation in Tibet and to finish his books in hopes of bringing international attention to the plight of Tibetan refugees worldwide. 


\section{CONTEXT AND DESIGN INTENT}

The project plans to establish a permanent site within Ottawa to house these scholars and dissidents, creating a place of shelter, knowledge and activism within the Canadian forest. The project will be a colony in the woods in the spirit of writers' retreats and artists' colonies, focusing on being a place to rest, to learn and to share.

Taking inspiration from projects like the Haystack Mountain School of Crafts and Yaddo Artists retreat, this project seeks to develop a community where scholars will have the opportunity to heal from the alienation and stress that comes from escaping relentless persecution, allow themselves a place to regain their composure and reclaim their humanity. The project is not just a place for scholars to continue their work and keep at their studies, it is a place for them to build connections and bonds with others around them and provide a place of REFUGE for their humanity and their souls.

Gatineau Park is located optimally, not only is it within close proximity to the political
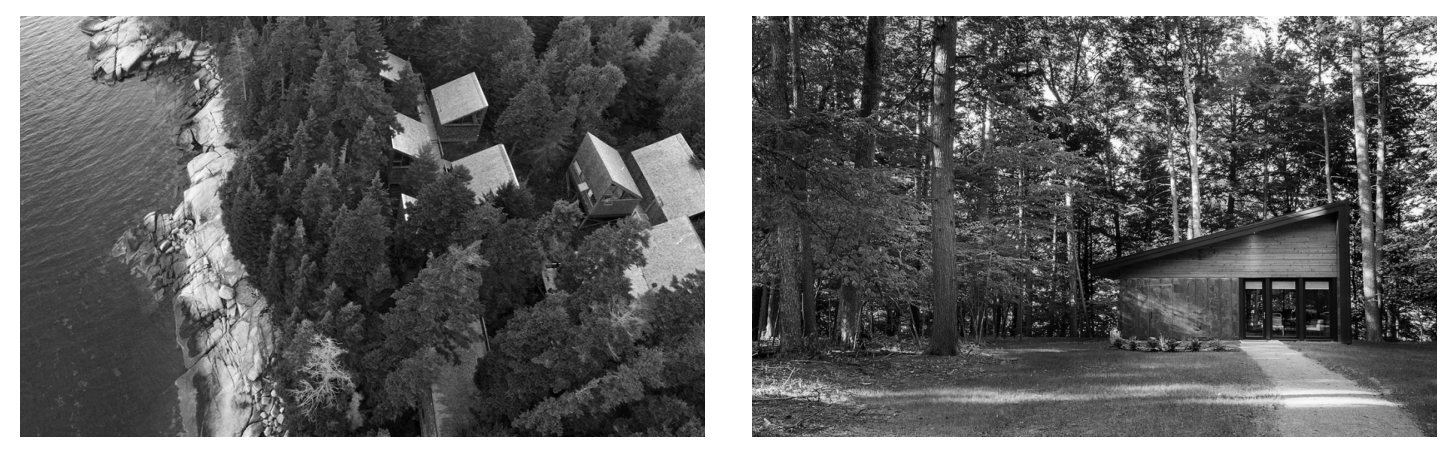

Figure 18 [ Photos of Haystack Mountain on the left and Yaddo on the right] 
center of Ottawa, but also to three universities with operating branches of SAR; Carleton University, University of Ottawa and McGill University. It is a beautiful conservation park, boasting over fifty lakes, the largest being Lac la Peche, Lac Philippe, Lac Mousseau and Lac Meech. The latter three form a chain of lakes through the center of the park, creating the Meech Creek Valley.

The park is partly situated on the Canadian Shield and consists of rolling hills and valleys, rock fields and beaches, large exposed boulders and escarpments of hard Precambrian rock. The wildlife in the park is extremely diverse with over $90 \%$ of the park being forested, due to Gatineau Park lying in a transition zone with the boreal forests of the Canadian Shield to the north and the Eastern temperate forest of the St. Lawrence Lowlands to the south.

The village itself only has a single entrance, a narrow access road turning off the TransCanada trail, winding its way through the trees and brush that keep the project hidden away from the public eye. The path terminates in a quaint little parking lot and a narrow dirt path piercing through the line of trees, reaching through to the meetinghouse.

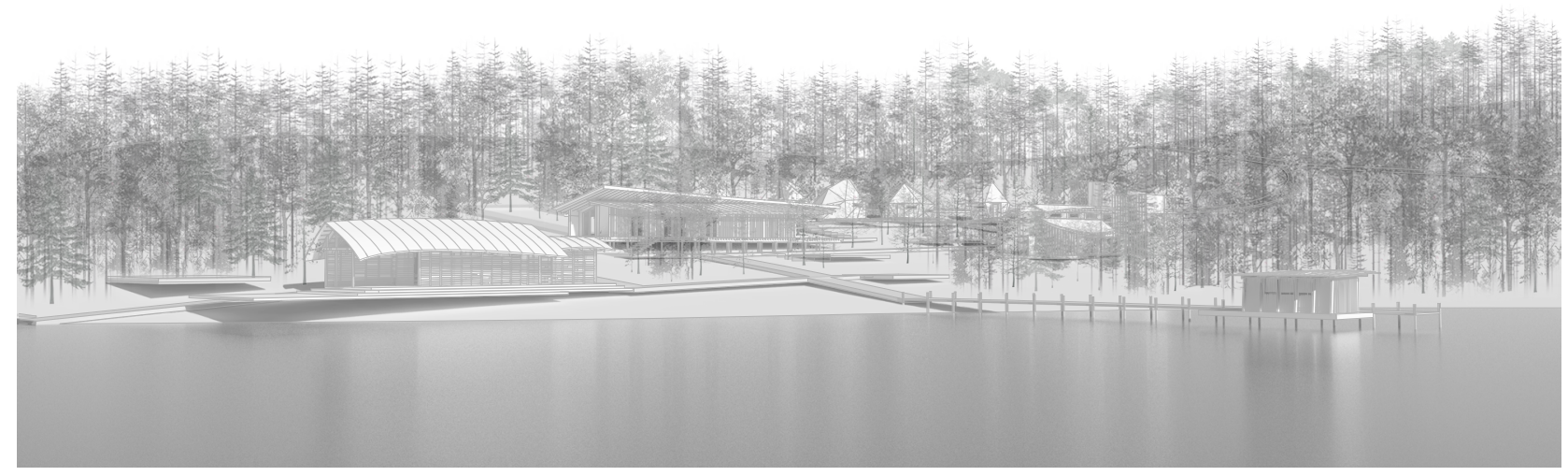

Figure 19 [ View of the retreat from out on Lac Meech ] 
The project is placed firmly within the landscape of the Canadian Shield, with buildings nestled into the steep rock hillsides, while others emerge out of the sloping granite shelf as the structures and spaces cascade down the hill to the water's edge. Walkways and decks weave around walls and scatter off, disappearing between the trees. They provide flat, level surfaces to transit across the site, winding between large boulders, lifted above the undulating, unforgiving, rocky landscape below. As they reach the shoreline, the walkways extend out across the water into two long docks, one reaching into Lac Meech and the other out across Macdonald Bay. Twisted skillion roofs are featured throughout the project with exposed rafters and draping surfaces resembling leaf-like structures, suspended amongst the treeline. Low sloping roofs mimic gentle, leafy canopies.

The buildings are designed to fit and blend into the surrounding landscape with a wood-to-wood philosophy, utilising the natural properties and aesthetics of local Canadian lumber. Most of the structures are built in the Canadian vernacular with timber framed buildings, sheathed in classic board and batten siding, carrying the verticality and rhythm of the forest across the project's many facades and structures. The project embodies Canadian heritage in its structures and styles, reflecting the importance and significance of the Canadian values embedded in its philosophy and design. Seeking to interact with the landscape, many of the buildings are set deep into the hillside, rising out of the escarpment and extending onto wooden platforms perched on a network of beams, with elevated boardwalks taking you between the trees. Leading from building to building, the boardwalks are offset by the tangle of walking trails winding across the site. The buildings themselves share an understanding of materials that are allowed to age and weather with the buildings and the site, reflecting the durability of knowledge and community. It tells of concrete, copper and stone, 


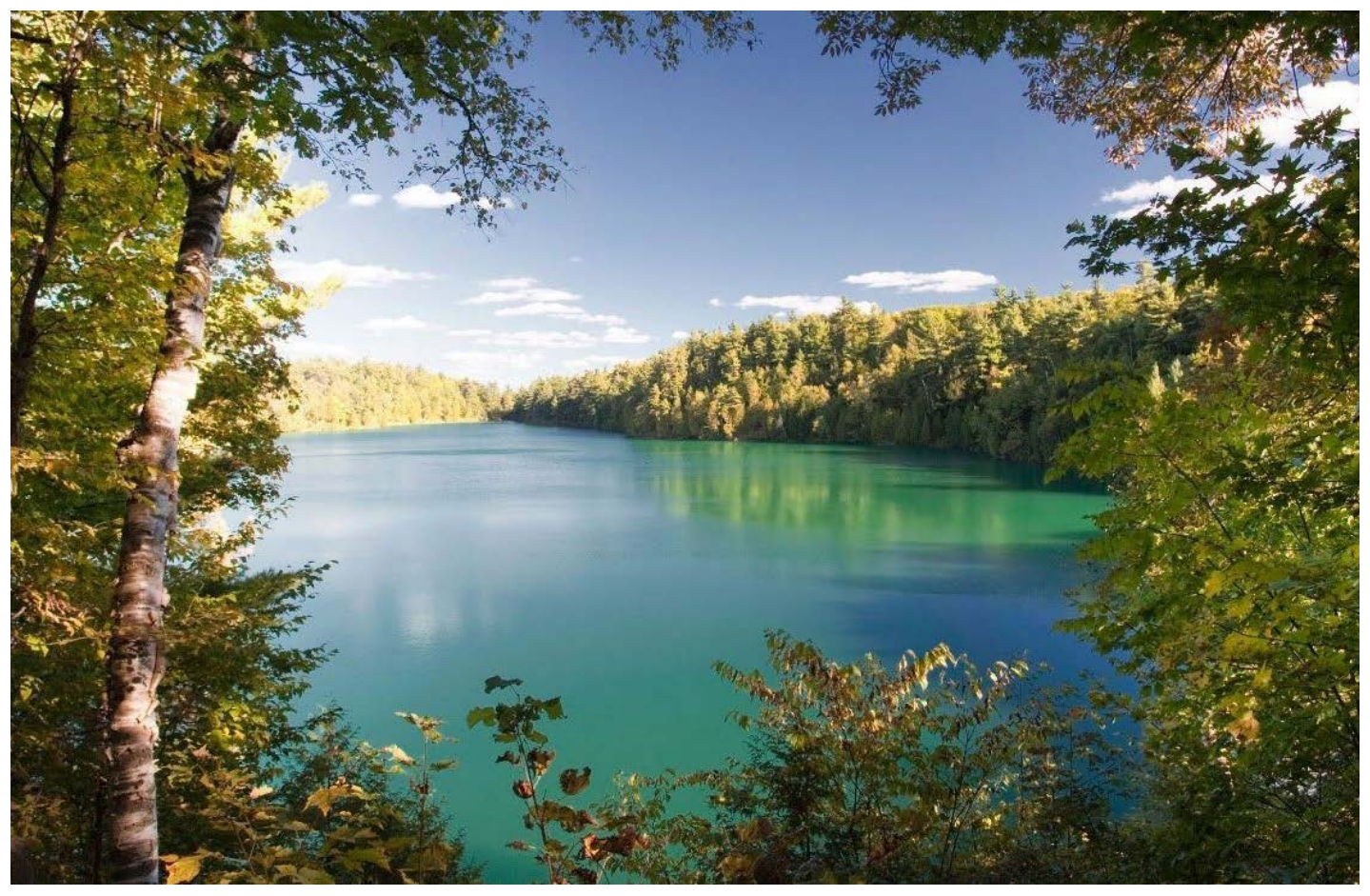

Figure 20 [ Photo looking out onto Lake Meech ]

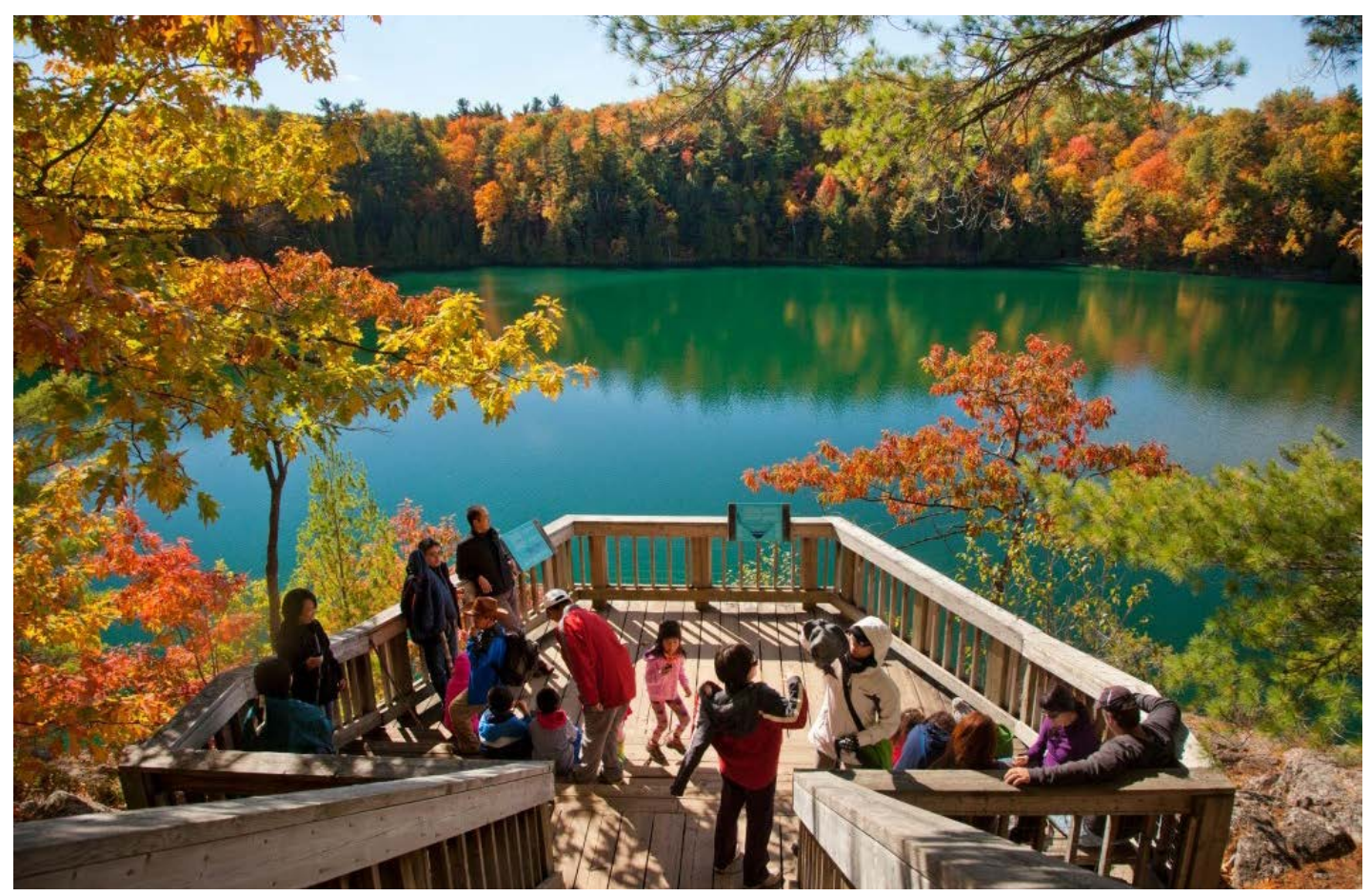

Figure 21 [ Photo at a Gatineau Park lookout point ] 
responding to both a human touch and the ravages of time. One of the motifs shared amongst the buildings are copper, standing seam roofs, allowed to patina and age with the cycles of the seasons and rain, taking on a dappled, weathered texture, mimicking the patterned look of the tree cover. The weathering on the board and batten siding, hewn from local cedar, takes on a grey, bare texture, developing a soft, deep wood grain, soothing to the touch be it from a hand brushing against it in passing, or underneath the pitter-patter of bare feet.

There is an emphasis on controlling light and channeling it through spaces meant for individuals and self-reflection, and spaces meant for the collective, for community and gathering. The use of strategically placed clerestories, inserted between split roof planes, deep window sills help to shape and direct light as it enters buildings and spaces throughout the project. 


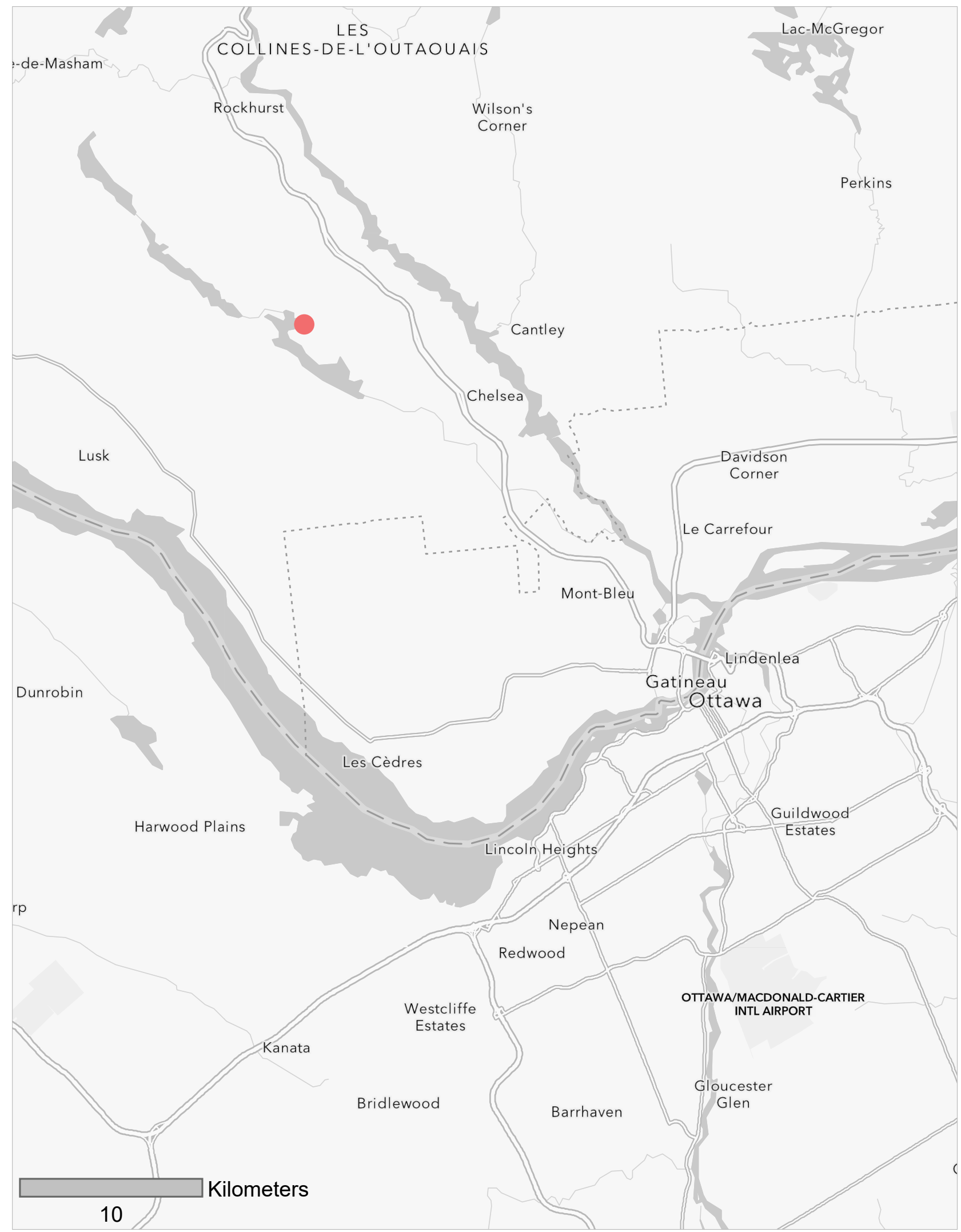

Figure 22 [Map of Gatineau Park and the site's relation to Gatineau and Ottawa ] 


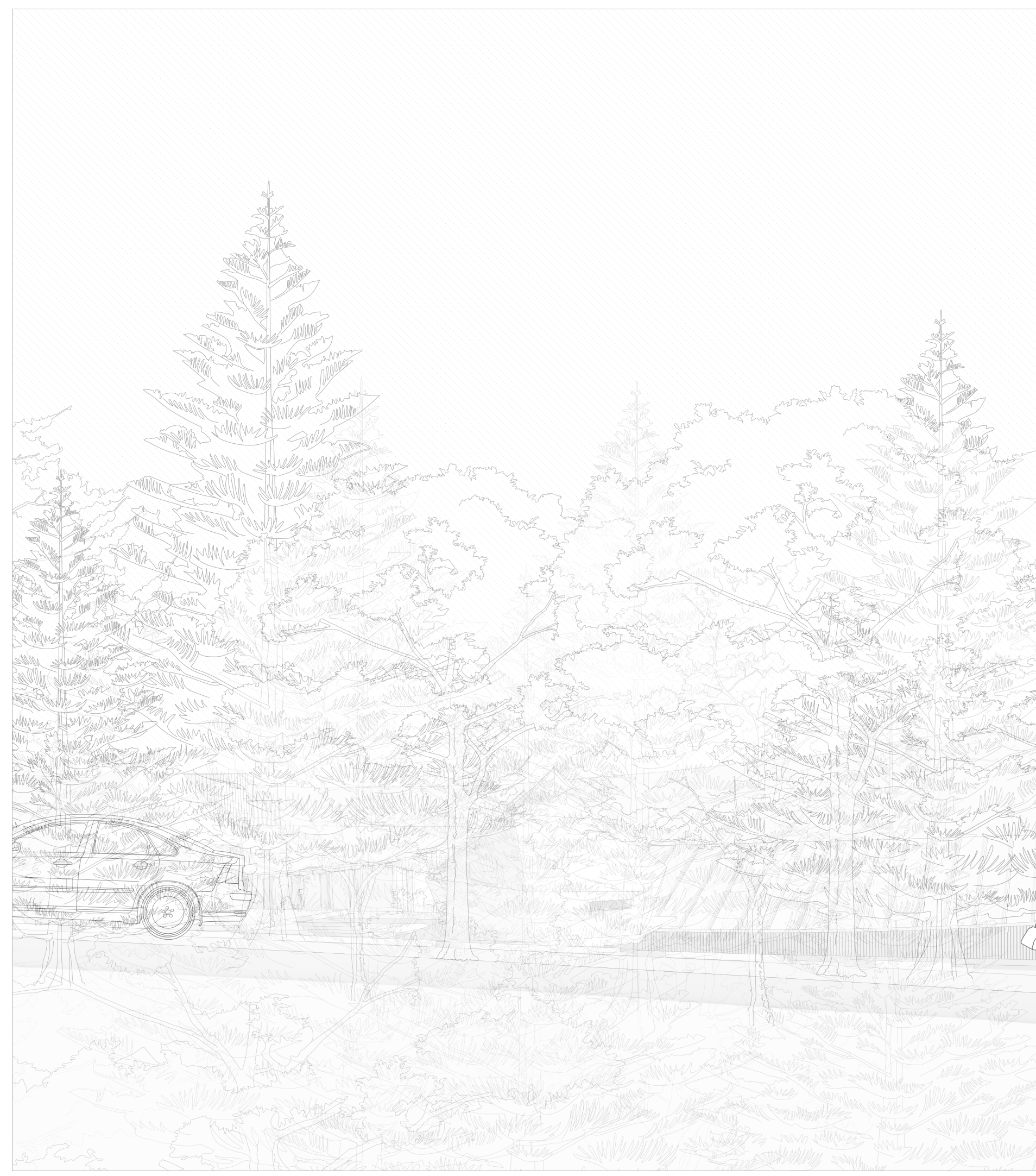

Figure 23 [Entrance to the project, cutting through a line of trees] 


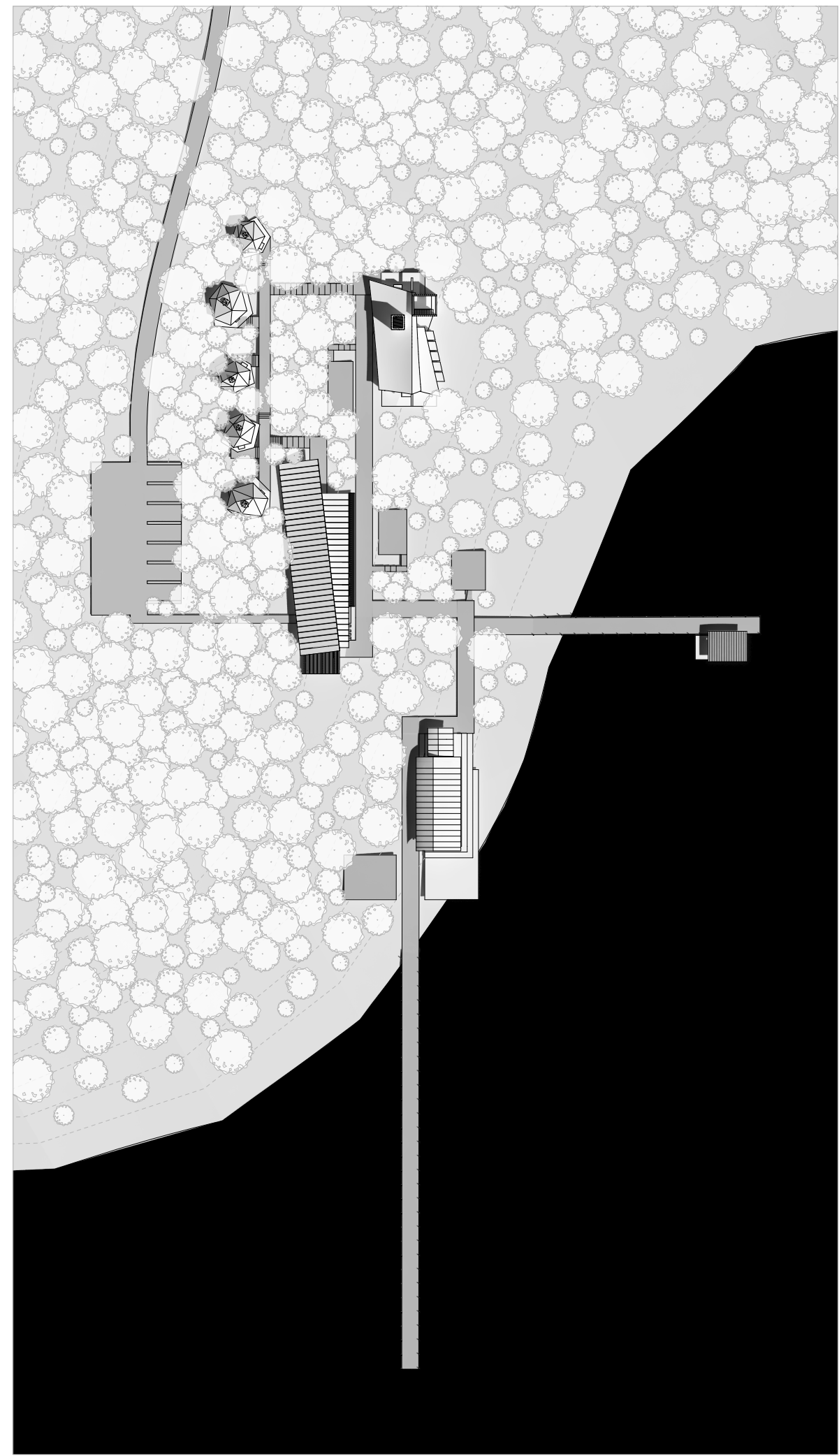

Figure 24 [ Site Plan drawing ] 


\section{THE PROJECT}

The Meetinghouse is the first building that you will come across, a low, gently sloping roof, rising out of the rocky slope and projecting out above the boulders scattered across the site. It serves as a gateway into the site, a place of passage and a place of gathering. It sets the tone of the project as a place that is not meant as a hideaway, but as a place to LIVE, a place to build community and experience nature in the presence of others.

The interior of the building is divided into a set of rhythmic bays with alternating sections of full height windows, solid wall panels and slatted screen doors, modulating

Figure 25 [ Scholars preparing lunch together in the meetinghouse ] 


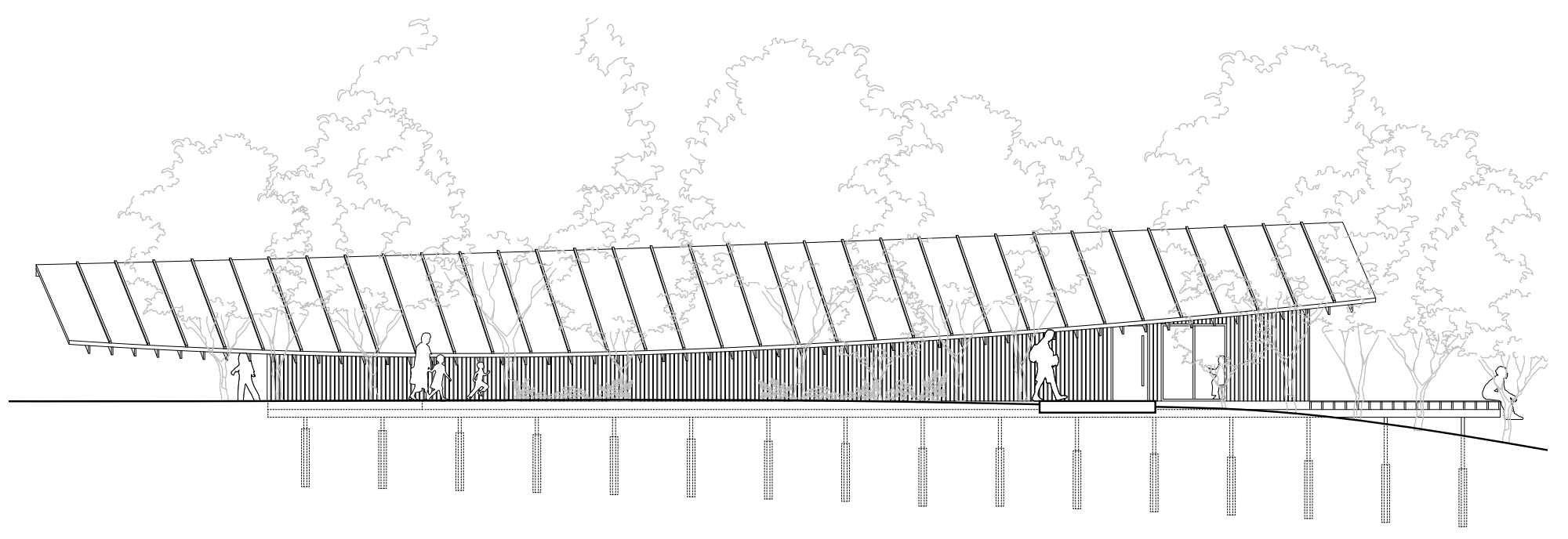

Figure 26 [ Elevation drawing of the meetinghouse ]

the transparency and permeability of both the space and the enclosure as you walk through it. The building is an undivided open loft space, organized around a series of open bays with flexible programmability and ample space for open gatherings and adhoc assemblies. On the far end, a row of full height doors allow the wall to open up, extending the interior space and blurring the lines between interior and exterior space, encouraging a style of living and community that incorporates a seamless transition from the inside of the house to the deck wrapping around it. A single elevation throughout, the accessibility of the meetinghouse encourages a constant shuffling and movement of furniture and programmes, facilitating a constant shift of activity and erasing the hard lines of inside/outside. A vaulted roof spans the space above, coming together at a large central ridge beam that runs the length of the building. The roof planes gradually separate above, coming apart and forming a clerestory and light shelf, spilling daylight across the interior. 


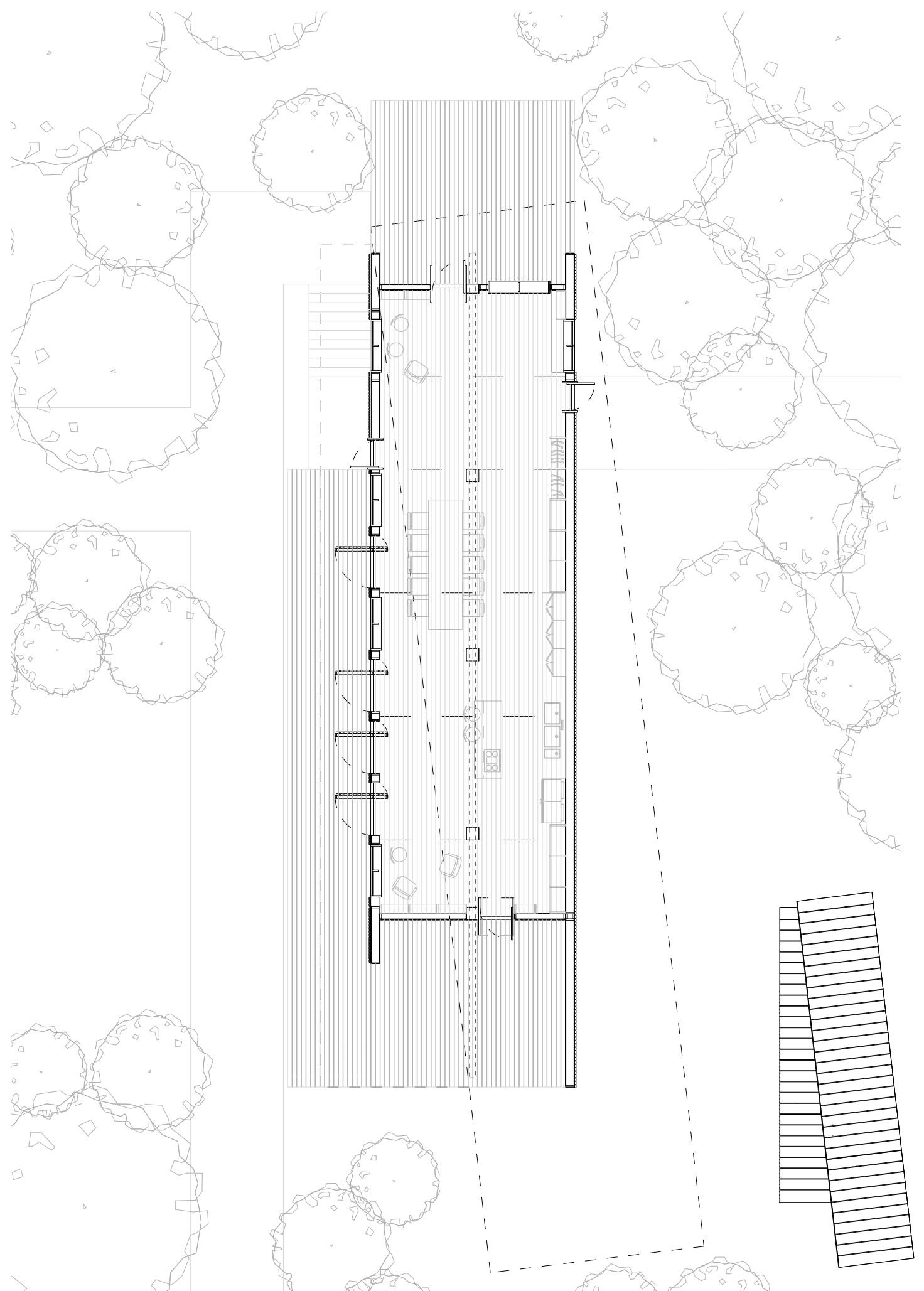

Figure 27 [ Plan drawings of the meetinghouse ] 
The meetinghouse is intended for communal use and group activities, serving as a multipurpose gathering space. It holds a communal library, housing a small, group curated collection of work and acts as a shared recreational reading space with chairs, benches and a small reading nook for anyone who wants to quietly unwind in a shared space. The meetinghouse also acts as a daycare or playspace for the children, giving them a space to frolic and spend time together before running off on expeditions onto the walking trails and lake.

Along one wall is a shared communal kitchen with a long galley counter. Ample cupboards and storage allow for large meals to be cooked, served, and cleaned up with everyone working together as a community. Across the counter is a big communal dining area intended for large, group meals, social eating and a bonding experience,

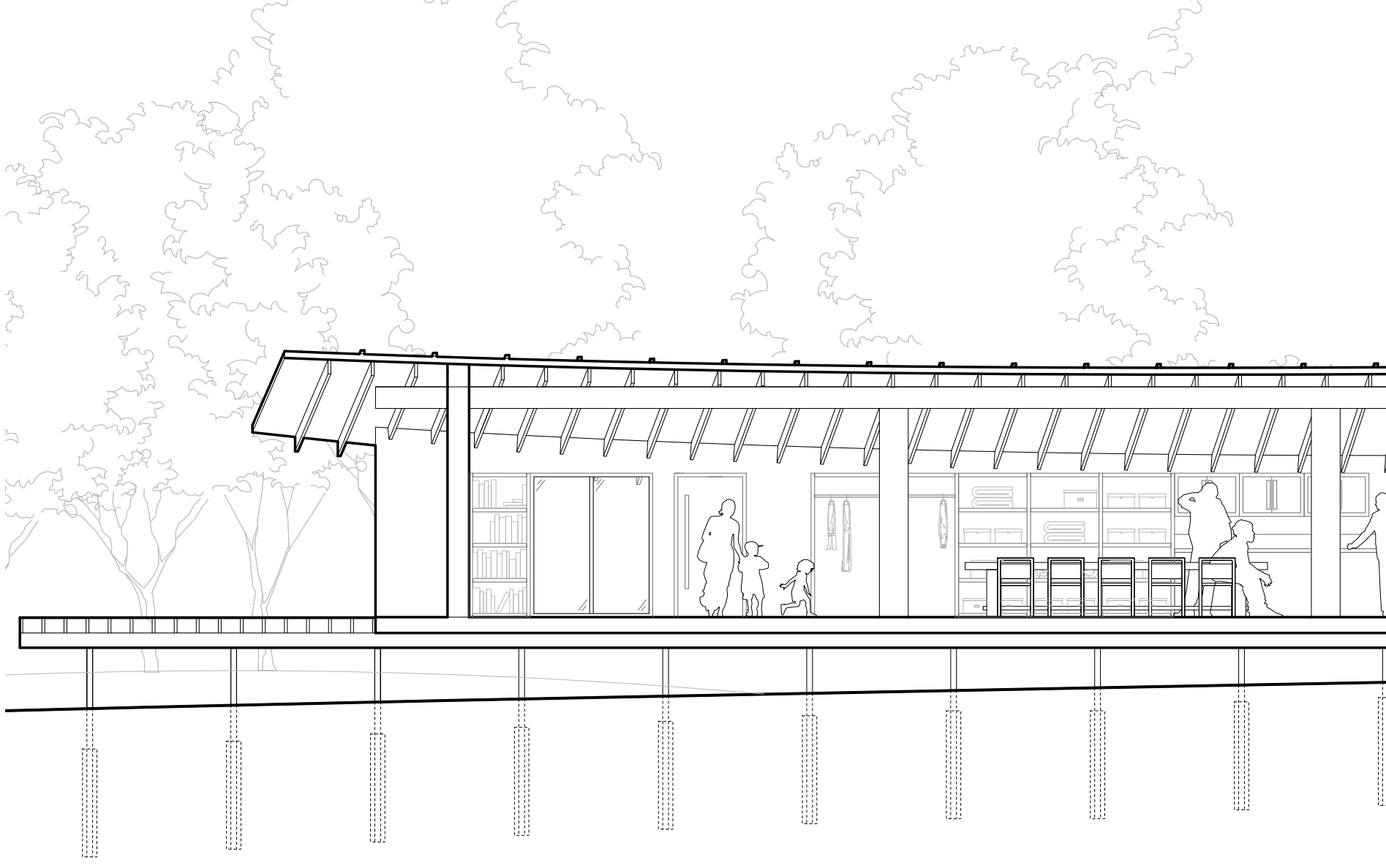

Figure 28 [Section drawing cutting through the meetinghouse] 
bringing the whole community together, serving and caring for each other as a family.

The meetinghouse is bookended by two large decks, one perched above the landscape on a grid of piers sunk into the bedrock, terminating aloft in the air with a panoramic view across the trees and onto the lake. The other walks out onto the landscape, accessing the cabins via a series of elevated boardwalks, winding its way between the old growth of the forest.

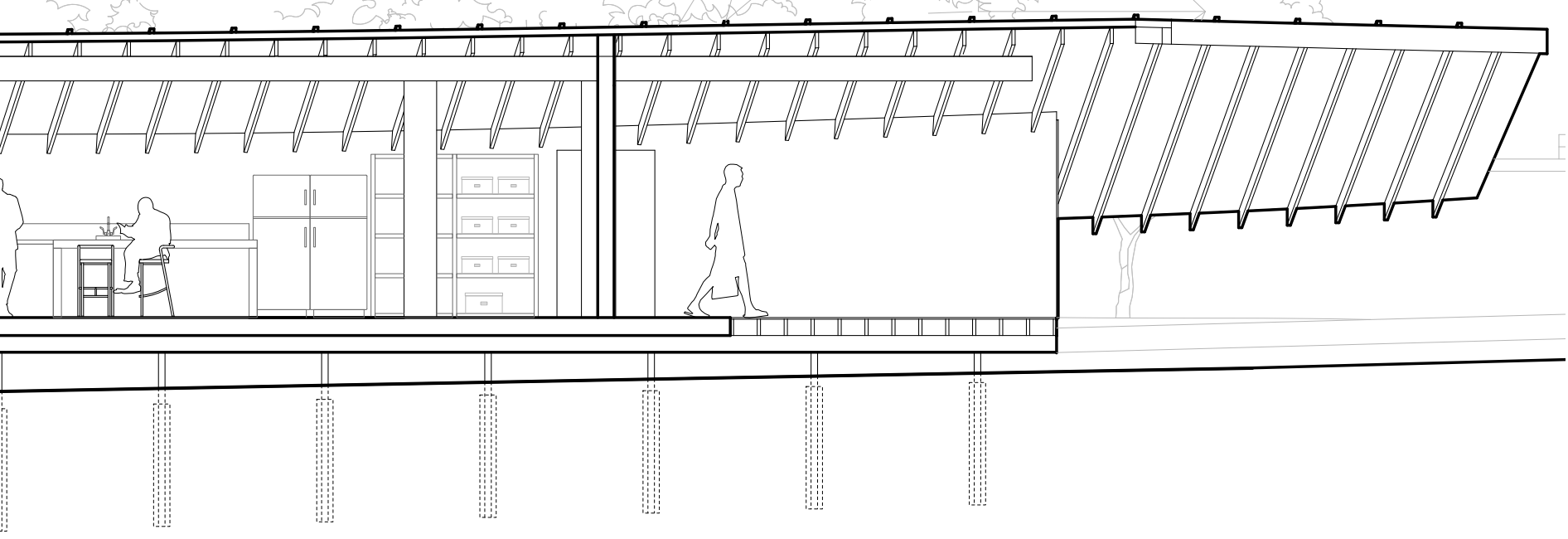




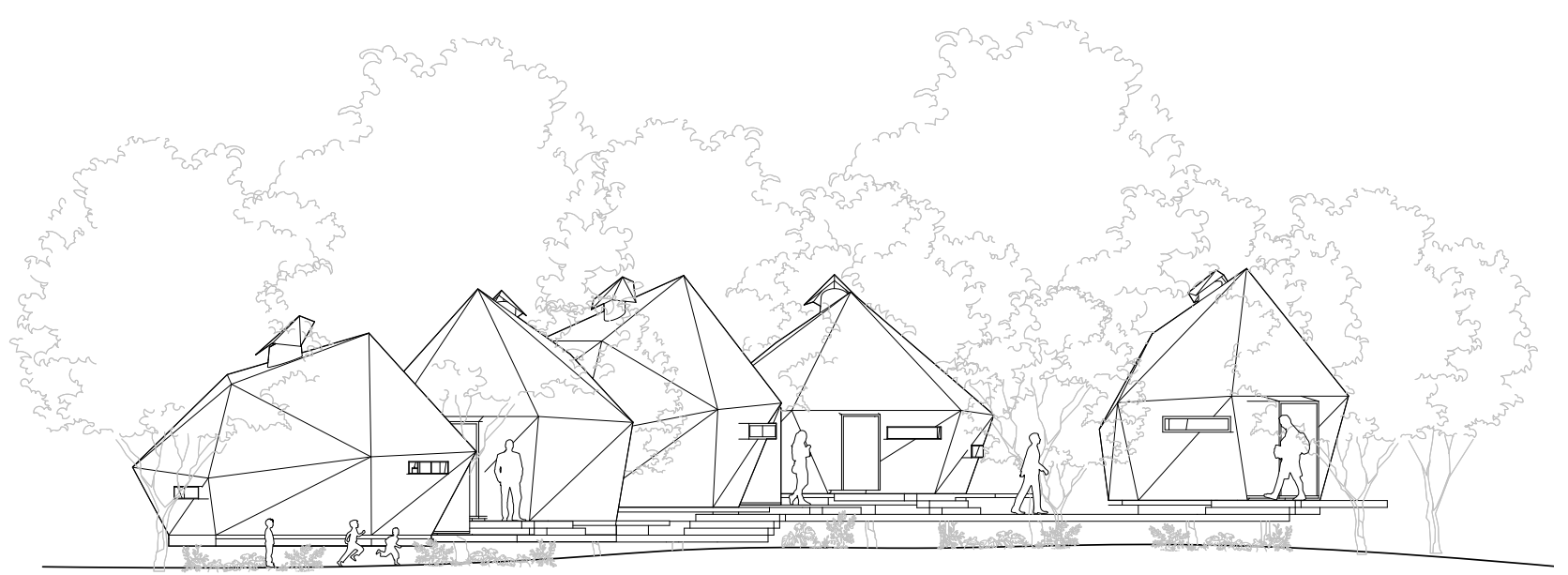

Figure 29 [ Elevation drawing of the cabins ]

The cabins are where the scholars at risk live. Cabins take the form of small, pods resembling angular, geometric treehouses perched upon a single concrete pillar, scattered among the treeline. They come in two sizes, a smaller size meant for individuals or couples with space for personal belongings and a private washroom with the intent of remaining cozy and functional, and a larger size to facilitate those who have arrived with children or family members, providing a larger space for multiple occupants. The cabins provide a private place, a quiet place to unwind and call your own.

Each cabin is built around a central concrete core which continues up from the decking on the floor and through the interior of the cabin, ballooning into a central hearth with thick brick walls, acting as a rounded masonry heater and tapers off at the top before 


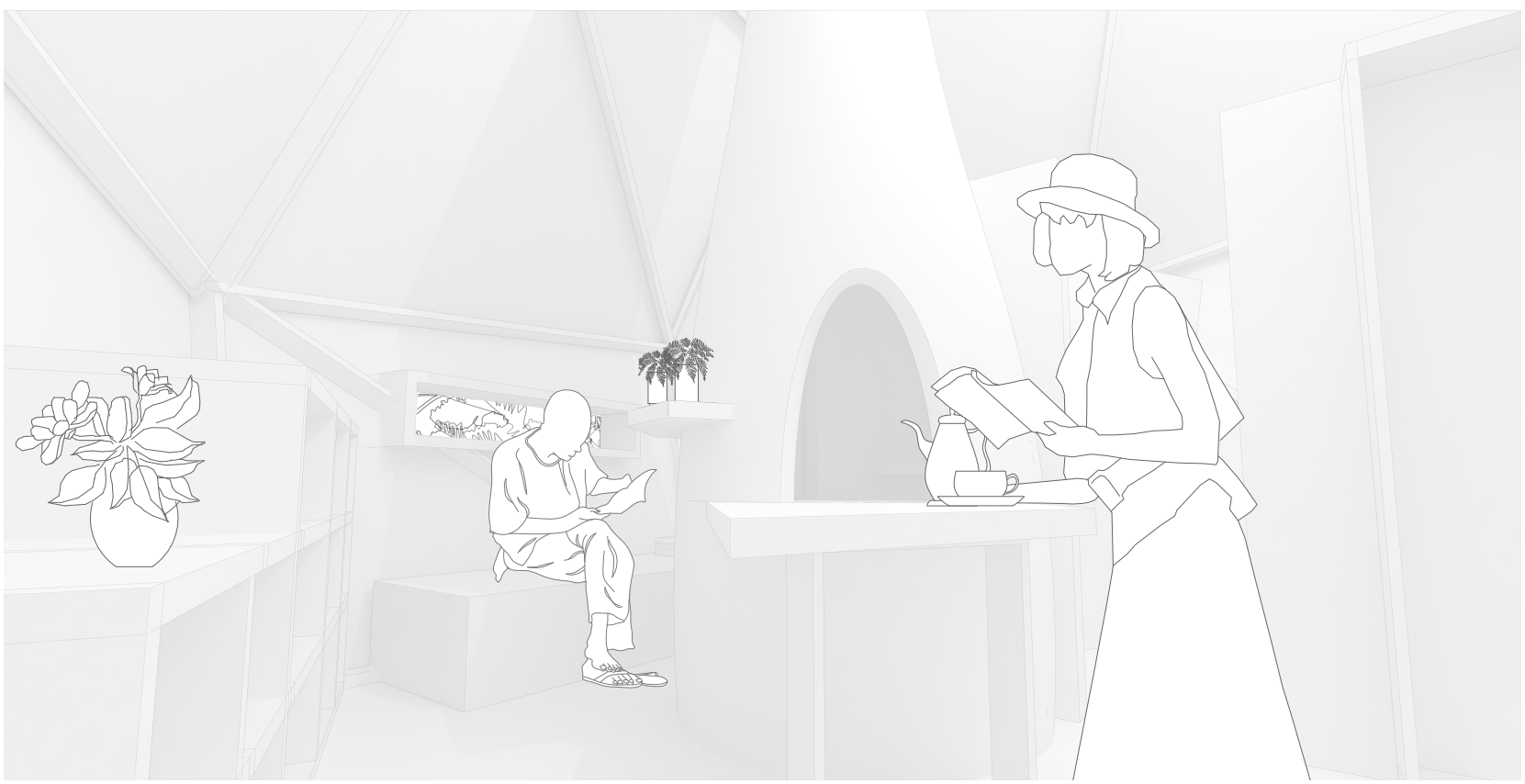

Figure 30 [ Scholar resting in their cabin, reading a book before bed ]
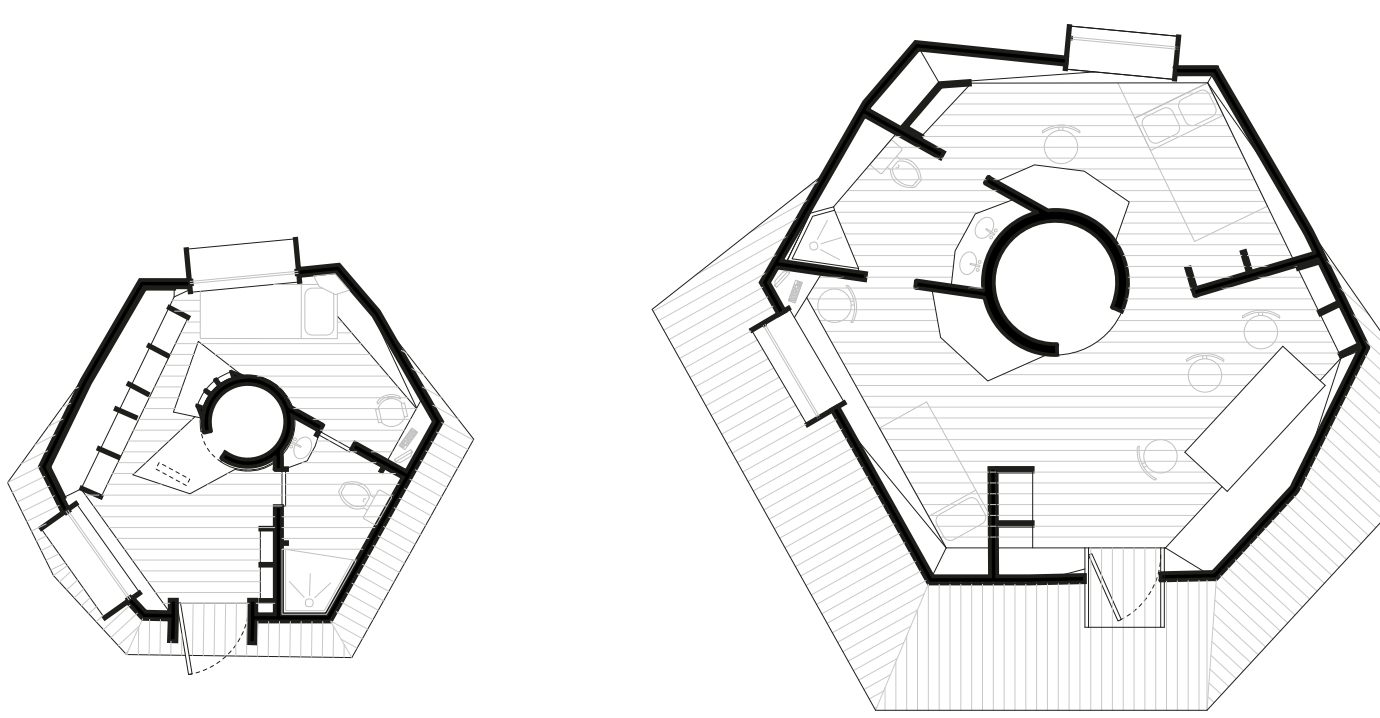

Figure 31 [ Plan drawings of the cabins ] 
exiting through the roof. A fire lit in its center warms the heavy brick core as flames lick the curved walls and warms the cabin like a wood burning stove, radiating heat and staying warm long into the night during cold Canadian winters.

Built-in shelves and cupboards line the slanted walls of the cabins, allowing its inhabitants space to store what belongings they may have been able to bring along from their homes. Other furnishing pinwheel out from the core, floating in space but anchoring themselves permanently to its core; a table to read at, a shelf to place knick knacks. Ribbon windows punctuate the angular shell of the cabin and deep window sills provide framed and directed views of the surrounding nature. A small deck lines the front of each cabin, leaving a sprinkling of private, yet public spaces on the boardwalks for gathering and mingling. 


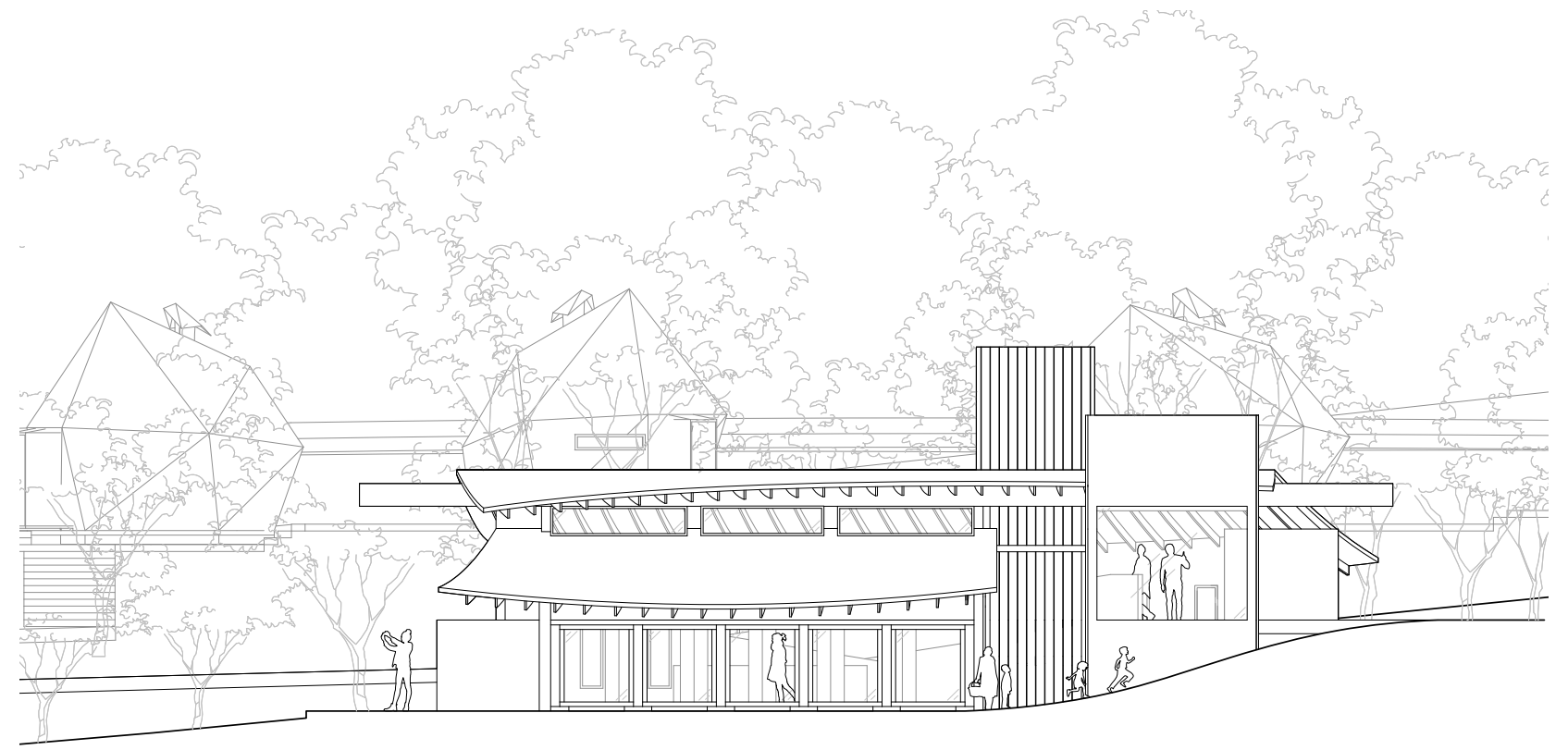

Figure 32 [ Elevation drawing of the library]

The library on the site represents the creation and preservation of ideas and knowledge and is intended to be used as an onsite place of study. A small but focused collection is kept onsite, with large sections able to be quickly swapped in and out by accessing university reserves from the libraries at Carleton, UOttawa and Université du Québec en Outaouai. In the center of its floorplan lies a concrete monolith, representing a vault, intended for the safekeeping of public record and the documentation of disappearing histories and censored peoples. The library provides a quiet meeting and collaboration space for scholars to continue their work or brush up on their studies.

The building is the largest on the site, with a split floor plan, descending half a storey below grade and a line of structural timber columns holding up a massive timber beam on which rests a high vaulted ceiling. A grand ramp circulates through the space and runs along the exterior wall past a series of tall windows, offering glimpses of the nature outside before turning back onto itself, depositing guests along the library's central 


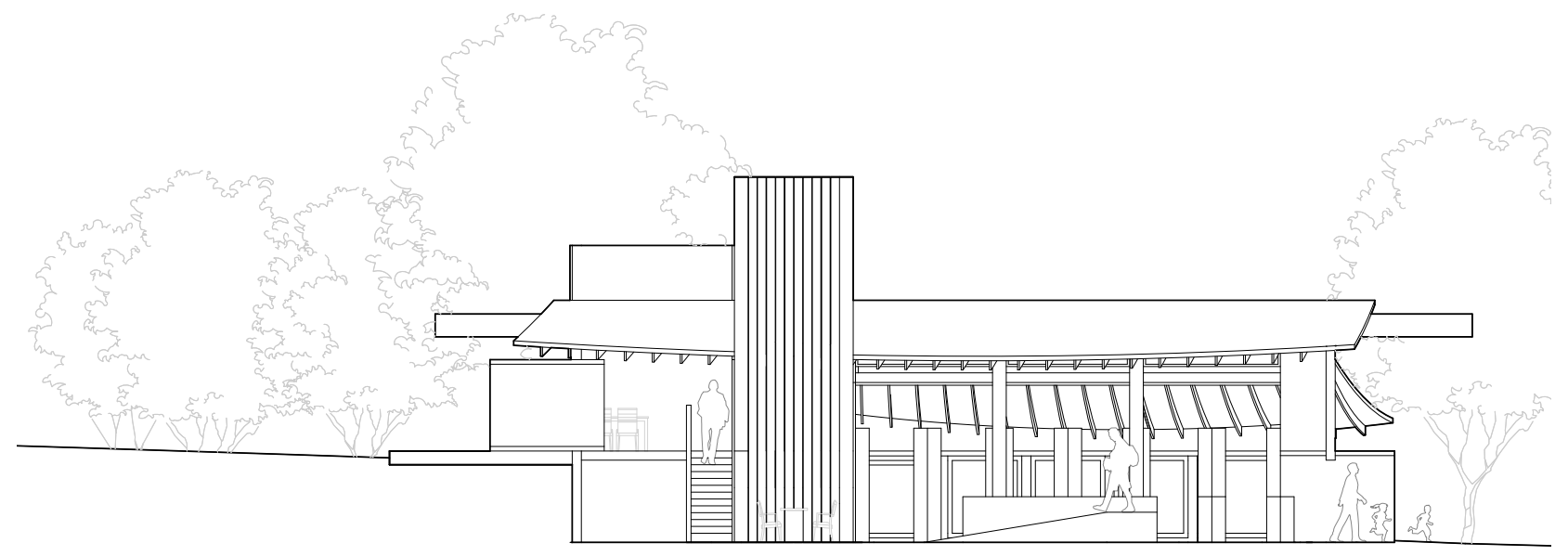

Figure 33 [ Section drawing of the library ]
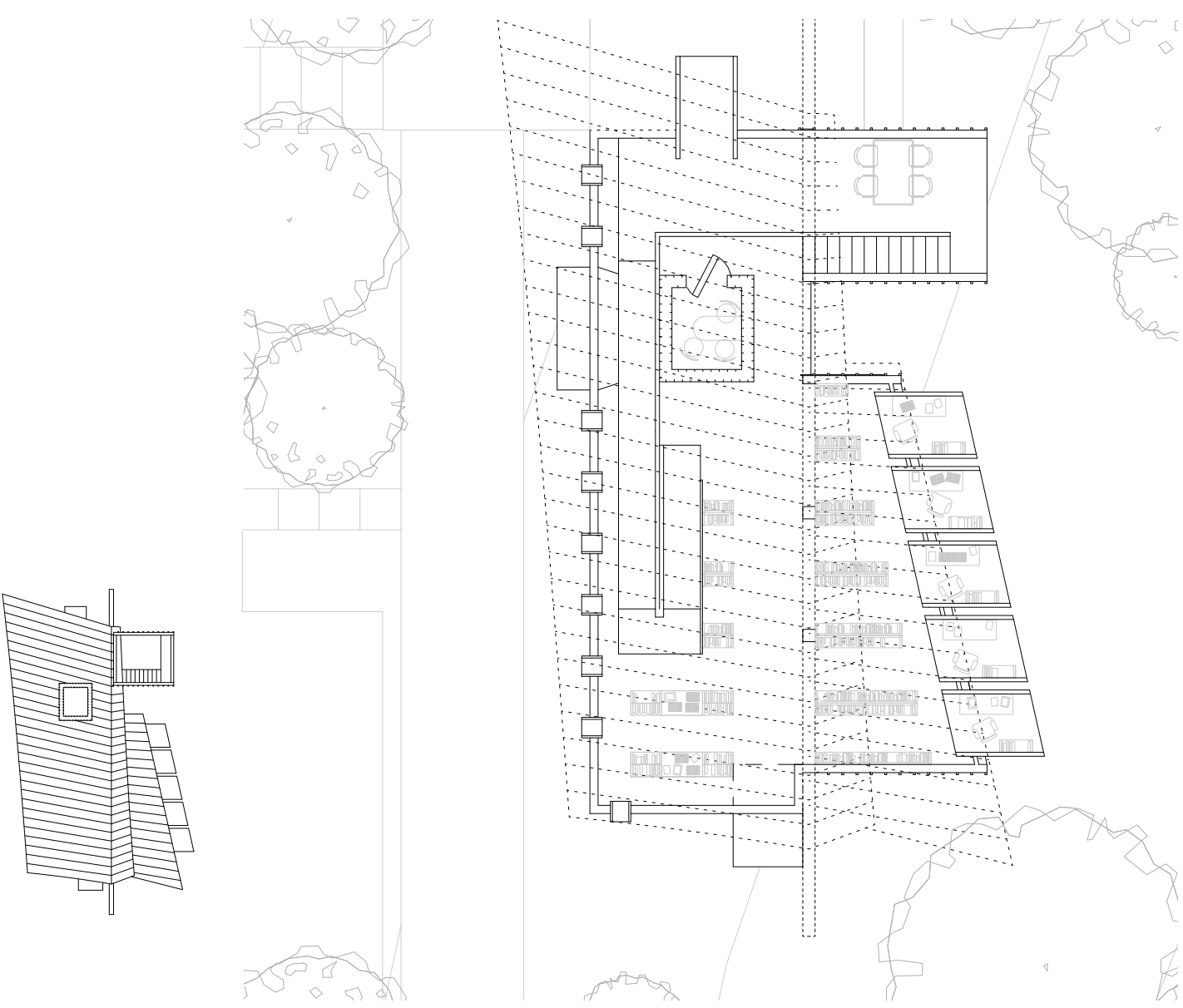

Figure 34 [ Plan drawing of the library] 


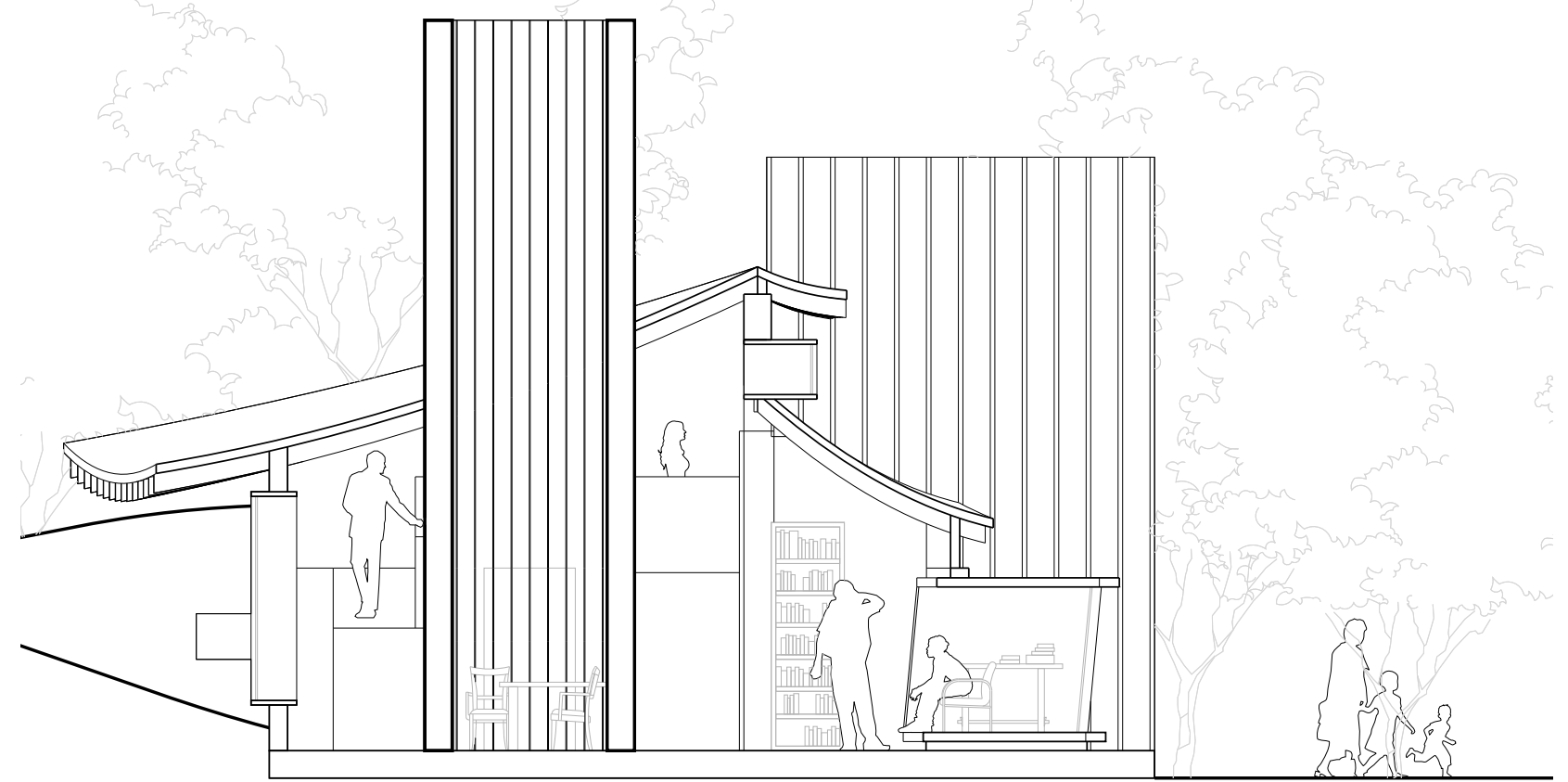

Figure 35 [ Section drawing of the library (study carrels)] 
corridor. Opposite the grand ramp are a series of tall bookstacks where the library's collection is kept on display. The tall stacks serve to break up the space and act as a soft screen to the study carrels, while the shorter stacks provide space to lay out collections of books, notes and artifacts for easy access.

Along the far wall, a series of study carrels resemble deep picture frames, forming individual cubbies for scholars to work alone within. Each carrel frames a different view out into the tree line and is equipped with a desk, bench and personal bookshelf. Carrels aim to isolate the individual from their surroundings, yet immerse them into nature and the trees beyond.

In its center, extending upwards and jutting out from the roof line is the Oral Histories Room, a hollow tower of concrete made with thick walls and lined with acoustical concrete block. A wide ribbon window at sitting height looks directly to the exterior, tunneling below the circulation ramp and draws soft light into the space while a skylight above showers the studio space in light, acting as a giant light well. Within the room lie a couple of stools and a small table upon which rests a collection of microphones, headsets and mixing boards. This is where the magic happens, where scholars, activists, refugees and guests sit together and share. Recollections, personal accounts, monologues, oral histories, transcripts, discussions; all are recorded here and preserved, kept safe within the public record and away from those who seek to censor. 


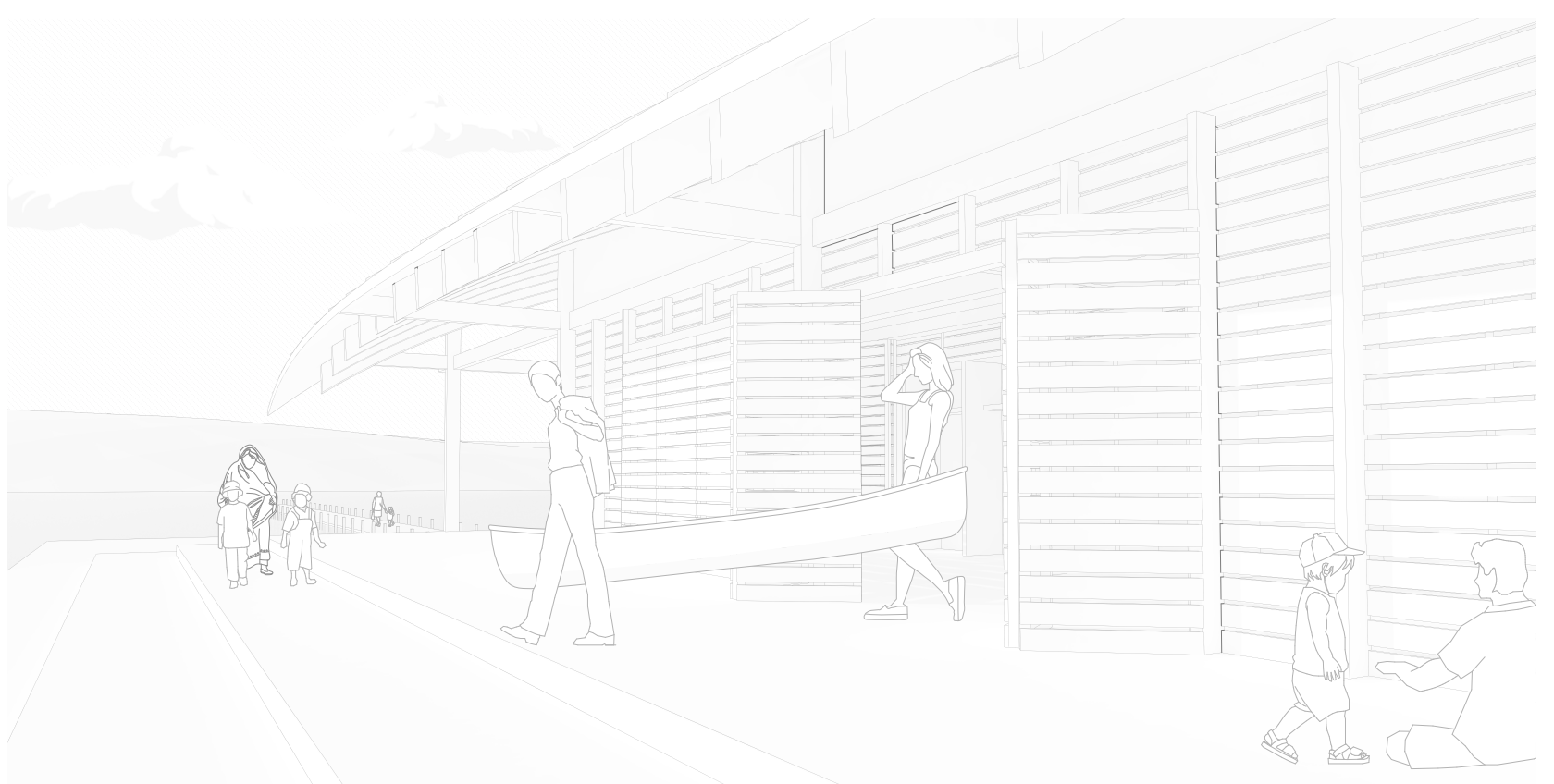

Figure 36 [ Scholars preparing for a day trip on the water ]

The hope of placing this community in Gainteau Park within the Canadian forest is to integrate nature, camping and a love of the outdoors into the lives of the scholars (all newly arrived to Canada). The equipment shed holds much of the camping and watercraft equipment needed to experience the Canadian wilderness and takes the form of a light and weatherproofed equipment shed.

The shed is built on a heavy timber frame with central roof beam, off of which 3 canoes and 4 kayaks will be hung to dry and kept out of the way. Its walls are lined with shelves containing all manner of equipment such as paddles, lifejackets, bail kits and larger camping equipment such as tents and portable shelters. Other, smaller equipment such as mess kits, sleeping bags and sleeping rolls will be stored in the meetinghouse and brought down in a pack to the Equipment Shed. 

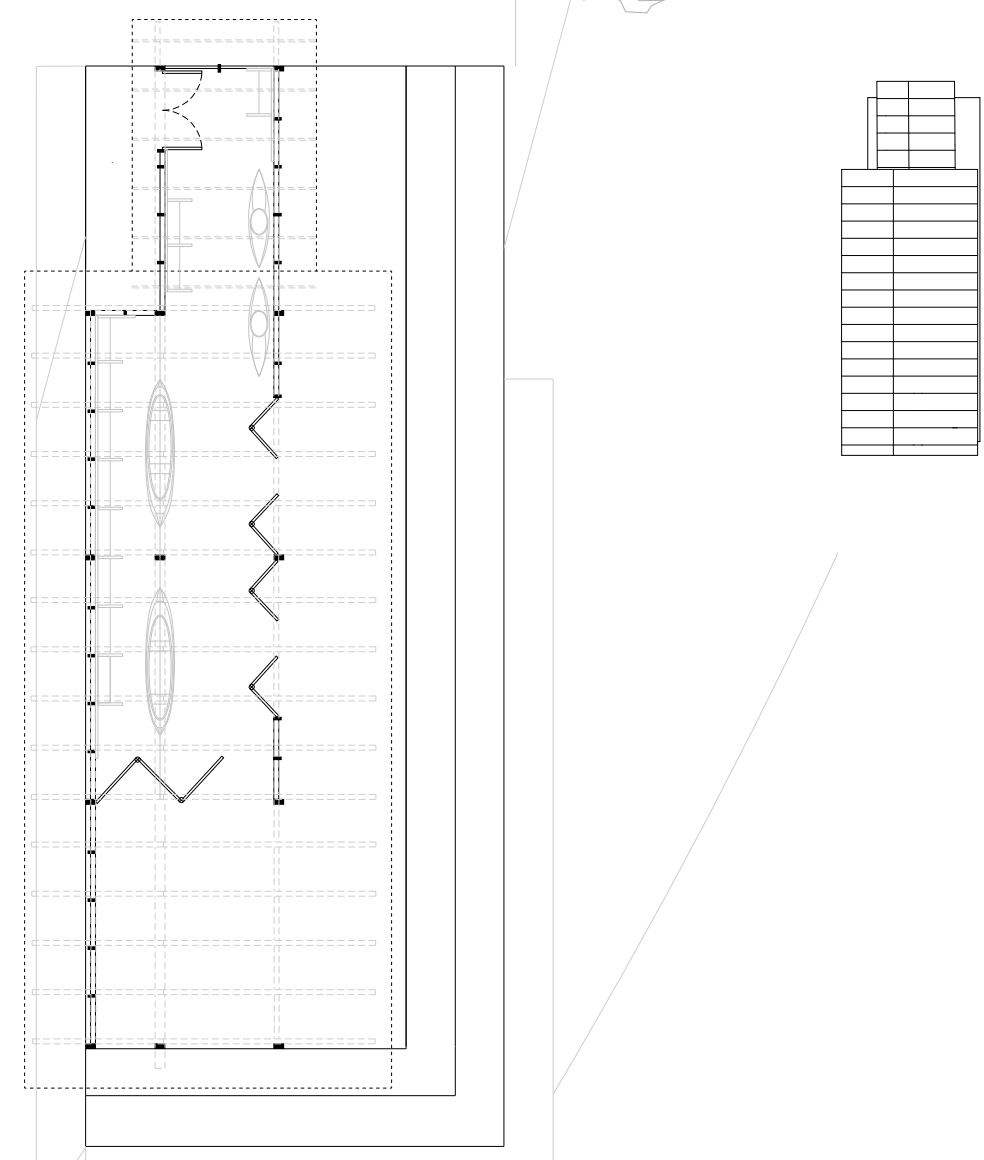

Figure 37 [ Plan drawings of the Equipment Shed ]

Patrons can gather the equipment they will require and place them into suitable day packs before heading out to the equipment shed where they can unhook a canoe/kayak from storage and carry it through the folding doors at the end of the building and place it into the water, where they can load up the boat and head off for the day's expedition. Upon returning they can unload any equipment onto the shallow dock and bring the watercraft through a second set of folding doors to hang up and dry off. 


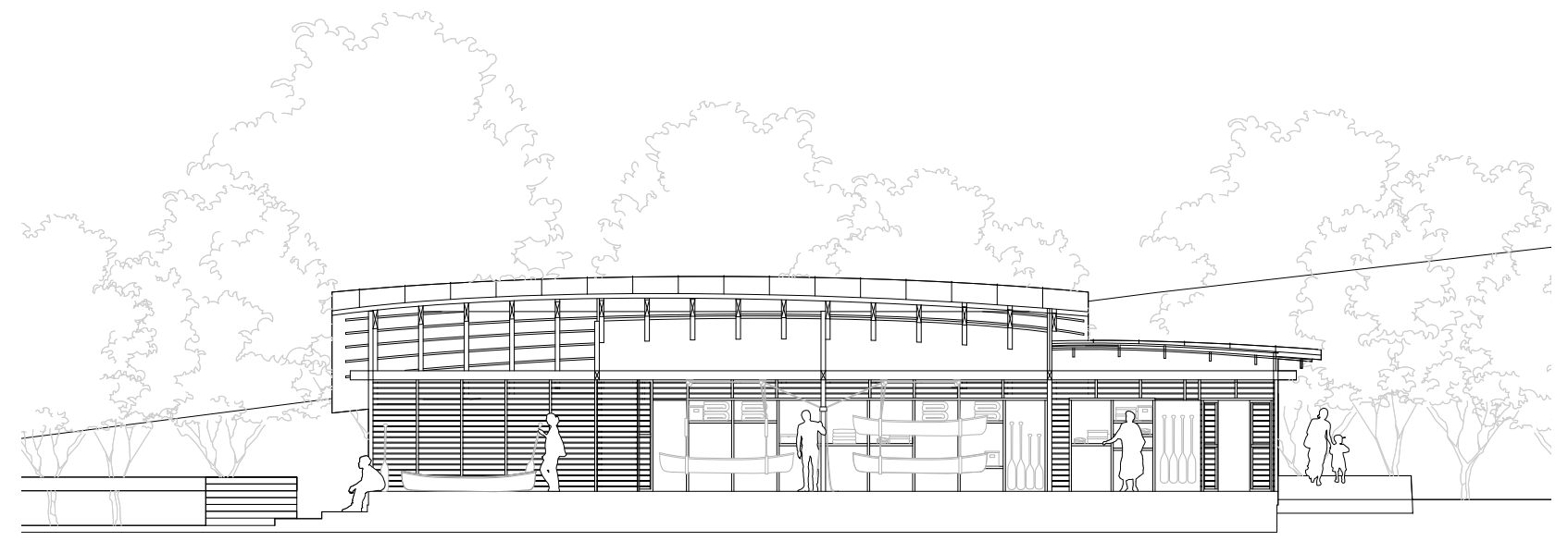

Figure 38 [ Section drawing of the Equipment Shed ] 
The Contemplation Space is a pavilion perched at the end of the Contemplation Deck, out on the water in the depths of Lac Meech. It serves as a quiet place of self-reflection, meditation or prayer. A semi-enclosed pavilion, the space is isolated from the rest of the project and is meant to be a place for individuals to distance themselves from the group and instead turn their focus inwards.

The pavilion sits alone out on the water, its entrance framed by two thick sheets of weathered copper, providing a gateway through which to enter. The buzz of nature and calls of the wild quiet down as the heavy walls of the structure close around and muffle outside noise; a quiet calmness washes over the space.

A low ribbon window cuts across the back wall, almost as if it were a handrail, guiding and drawing the eye around the corner as the central chamber opens up and reveals a square opening floating on the other end of the space. Through it, the rest of the project sits centered within the deep frame, like miniature versions of themselves, far off in the distance. 


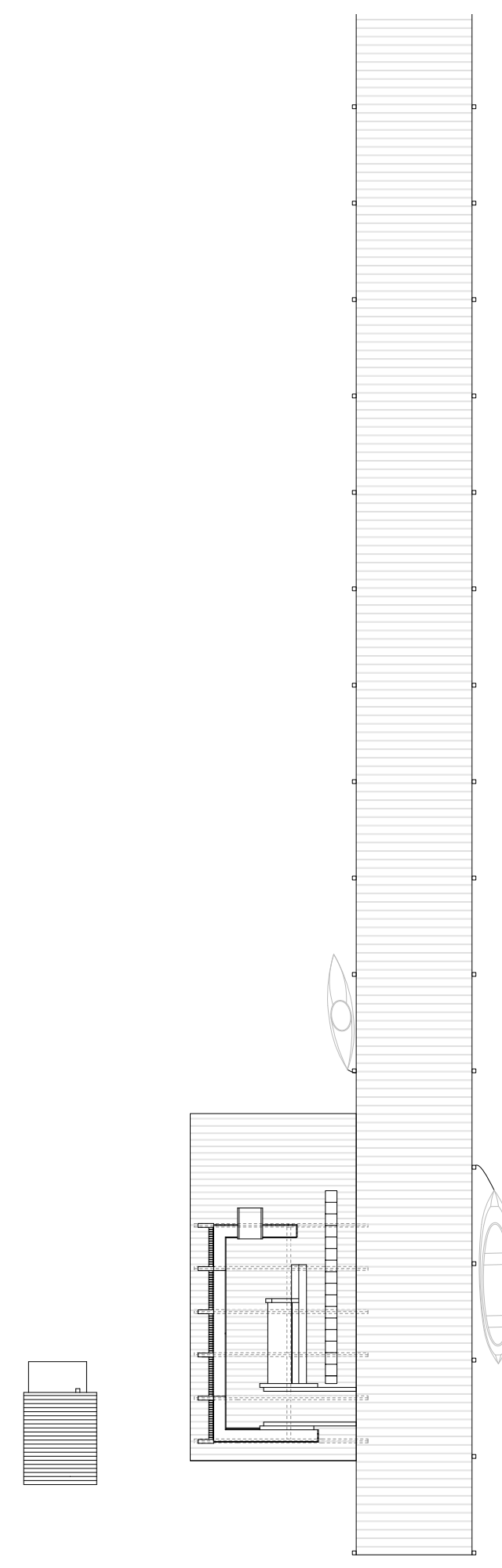

Figure 39 [ Plan drawing of the Contemplation Space ] 


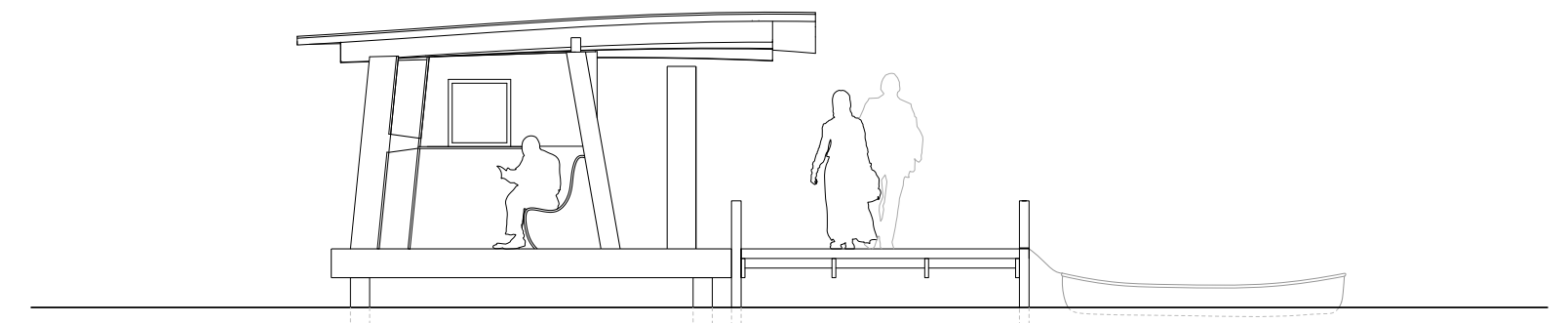

Figure 40 [ Section drawing of the Contemplation Space ]

A curved plywood bench creeps into view, opposite to the low ribbon of light which serves as an expansive viewport over the water and across the lake. As it starts to rain, the roof releases a muffled rattle, the pitter patter of raindrops drowning out all other sounds and distractions and the ripples of rain hitting the surface of the lake provides a mesmerizing backdrop.

Seconds drag on. Minutes pass. Hours go by; the only indication of the flow of time being the shadows reaching over the lake, and the light creeping back over the horizon. 


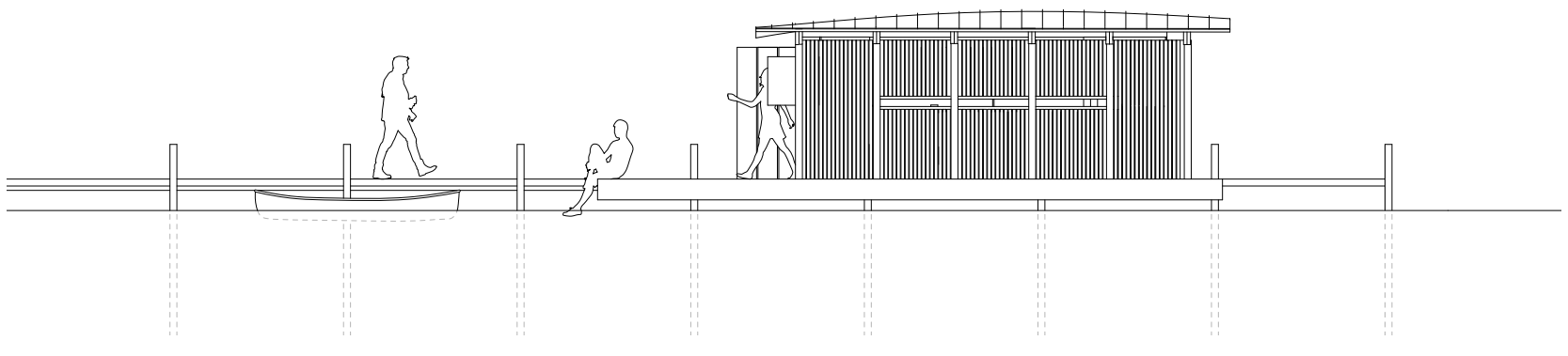

Figure 41 [ Elevation drawing of the Contemplation Space ]

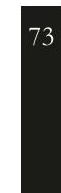




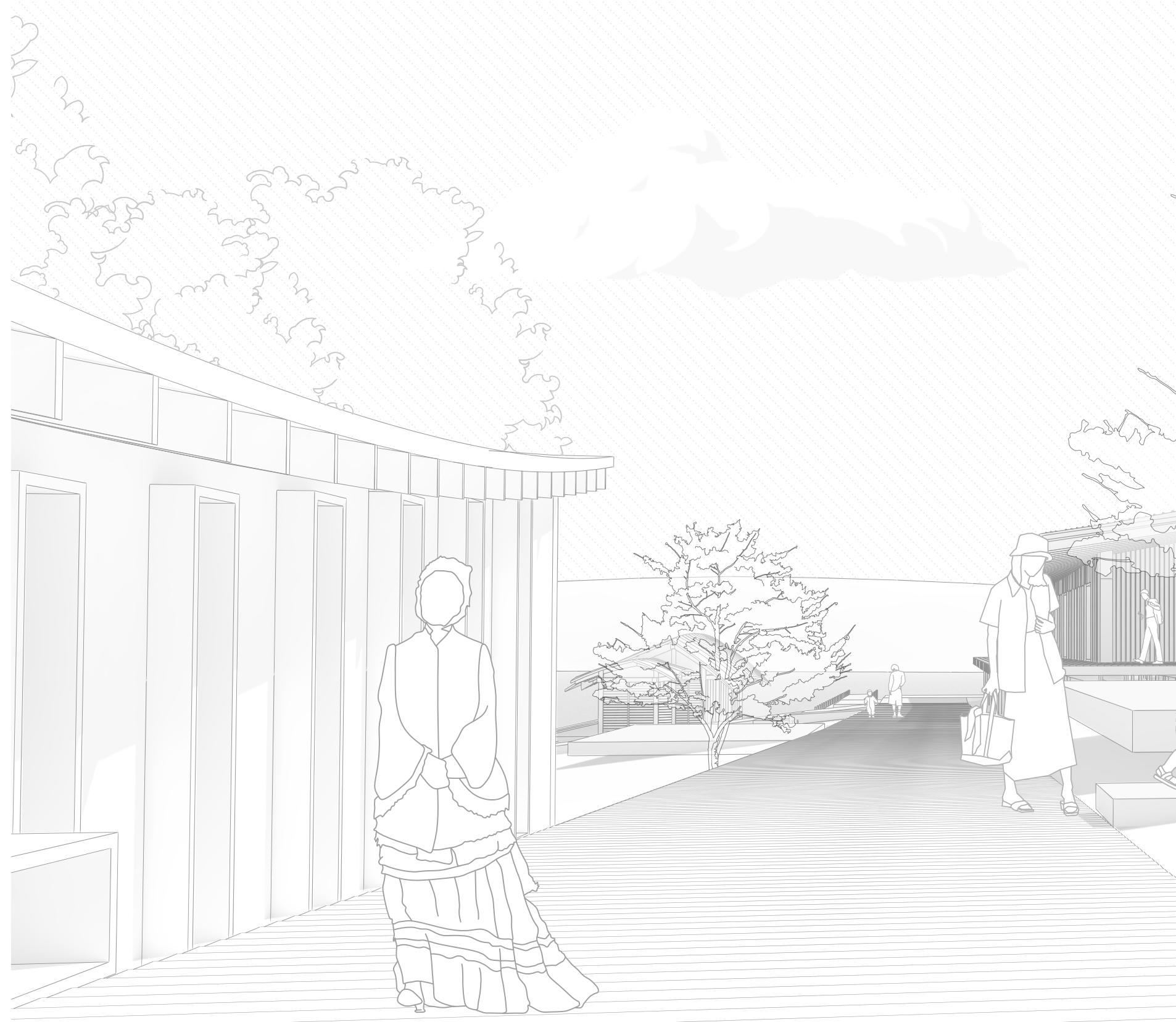

Figure 42 [Entrance to the project, cutting through a line of trees]

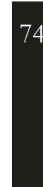




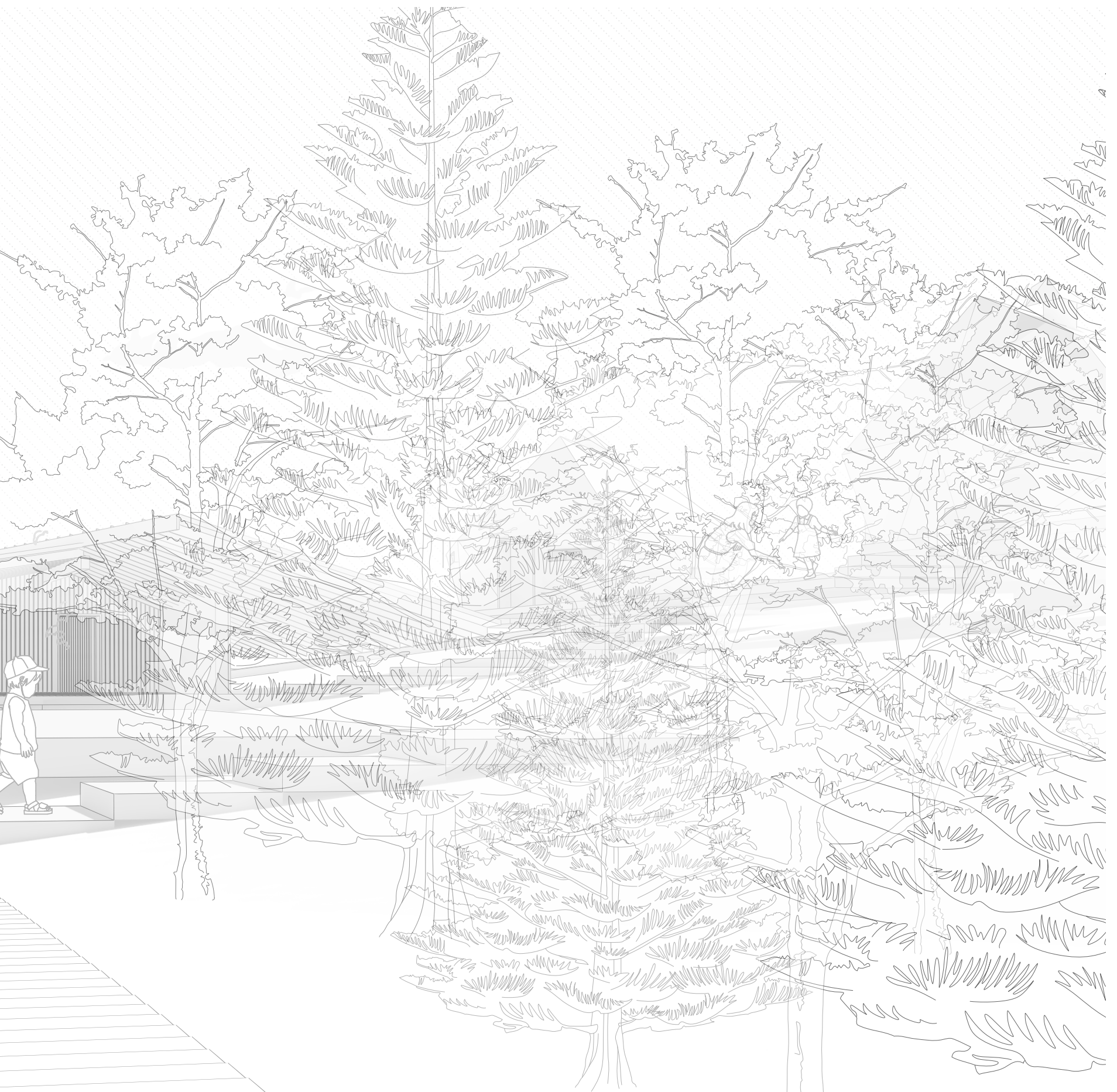

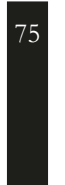




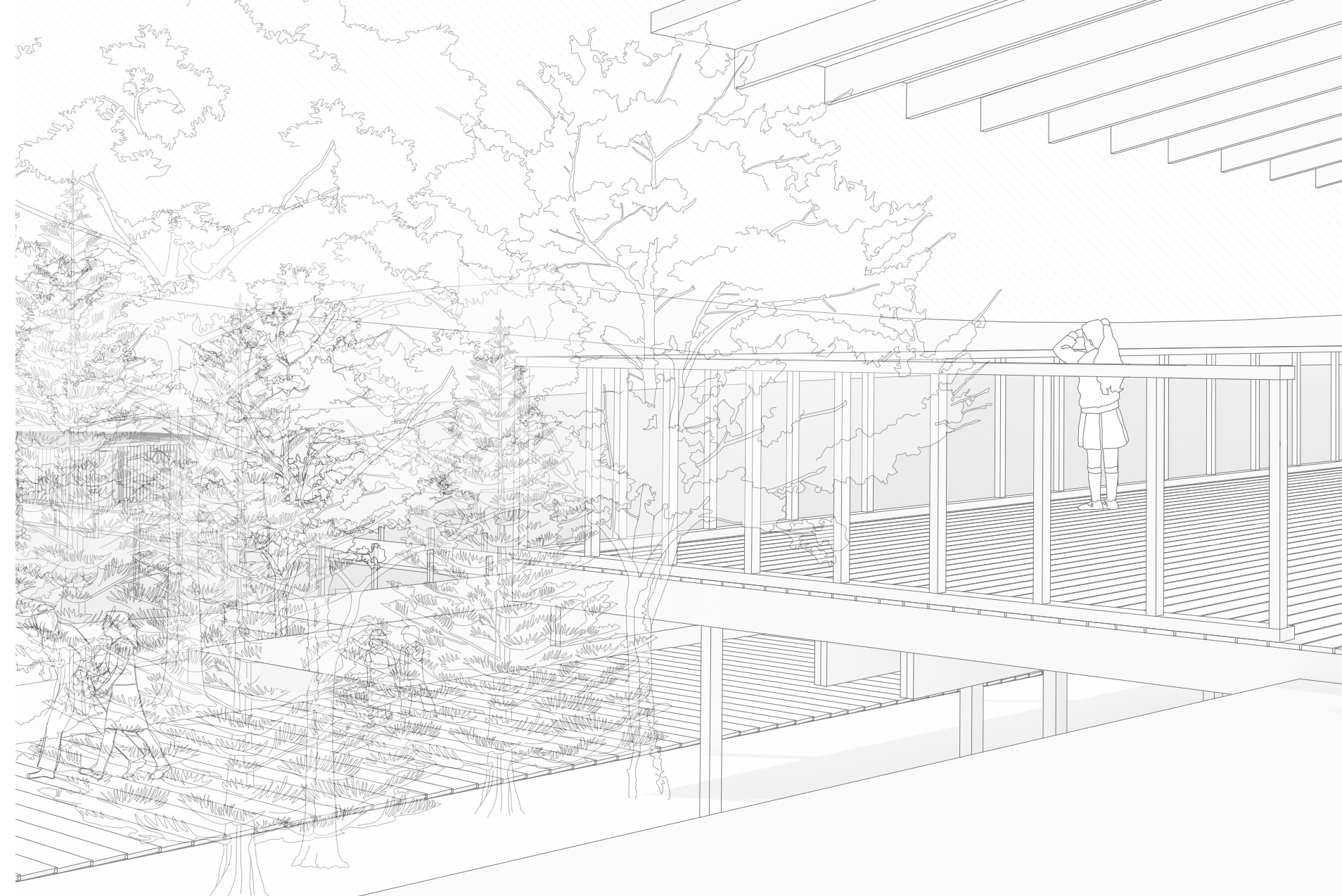

Figure 43 [Scholars entering the meetinghouse] 



\section{CONCLUSION}

Even as this project wraps up, the conditions of human rights in Hong Kong and across China continue to deteriorate. With the CCP still cracking down on freedoms of expression, free speech, and crushing all remaining hope for democracy—the people of Hong Kong and elsewhere are being silenced, arrested, and jailed with little to no recourse. Without significant outside help, the future looks bleak and there will soon be no one left to speak out for the rights of people and to oppose the CCP. While the passing of the National Security Law stifled political dissent and opened the door for interference from the central government, we will have to wait and watch as further actions by the CCP bring about the end of Hong Kong's autonomy and its identity while further eroding personal freedoms in China.

The Carleton University branch of Scholars at Risk was established together with the University of Ottawa branch and joined the SAR Network in 2014. Carleton SAR has hosted six scholars, who have taught and researched at six different departments within the university. This year, Carleton was able to host two at-risk scholars with two-year appointments, financial support, and the creation of new initiatives and student divisions of the branch. I see my project as a vision for the future of SAR. My hope is to propose a more hands-on approach to the transition and experience of the scholars and their arrival in Canada. It is therefore a prototype for expanding the program to many universities across the country. These new SAR shelters - each in different landscapes stretching from the Maritimes, through Quebec and Ontario, over the Canadian Shield, across the Prairies, and beyond to Western Canada - will foster 
the building of exiled intellectual communities and their commitment to freedom and justice as they build new relationships in their new home. With its focus on immersion in nature and a commitment to dialogue, communication, and open discourse, the project highlights the importance of retreating from the world in order to think about ways to make it better. Free from surveillance, free from threat and unjust persecution, this peace of mind is crucial to a scholar's ability to think critically about difficult politics.

I hope the project will be useful in working with the SAR initiative in the future, allowing it to protect scholars and academics from all over the world. While my focus was on those threatened by the CCP and China, it was never intended to be limited to those escaping persecution from one totalitarian state, but for everyone under threat from the totalitarian state, regardless of who they are or from whom they are running.

On March 22, 2021, the European Union and the United Kingdom issued joint declarations condemning the actions of the CCP and have issued sanctions on Chinese officials for human rights abuses and genocide in Xinjiang, its first sanctions on China since the 1989 Tiananmen Square Massacre all those years ago. The United States of America and Canada have followed suit, imposing parallel sanctions on Chinese diplomats, freezing their assets and banning their entry. It seems some of the world's democratic juggernauts have finally decided that enough is enough.

In light of these events, the project acts as a small, modest, hopeful protest. It stands as a commitment to Canada as a site of democracy and free speech, and as a firm opposition to the totalitarian state. I believe architecture can embody these values and help give a voice to those who have had theirs taken from them. 


\section{NOTES}

1. The Editors of Encyclopaedia Britannica, "The Treaty of Nanjing," Encyclopedia Britannica, February 9, 2019, https://www.britannica.com/event/Treaty-ofNanjing.

2. Steve Tsang, The Modern History of Hong Kong, (London: I.B. Tauris, 2004).

3. People's Republic of China, "The Constitution of the People's Republic of China," The Basic Law of Hong Kong Special Administrative Region of the People's Republic of China, March 11, 2018, https://www.basiclaw.gov.hk/en/basiclawtext/ index.html.

4. Kris Cheung, "Hongkongers identifying as 'Chinese' at record low; under 10\% of youth 'proud' to be citizens - poll,’ Hong Kong Free Press, https:// hongkongfp. com/2019/06/28/hongkongers-identifying-chinese-record-low-10-youth-proudcitizens-poll/.

5. Nury Vittachi, “Hong Kong, City of Broken Promises,” Asia Sentinel, https:// www.asiasentinel.com/p/hong-kong-city-broken-promises; Ming Sing, "Hong Kong's Democrats Hold Their Own,” Journal of Democracy 20,1 (2009): 98-112, https://www.journalofdemocracy.org/articles/hong-kongs-democrats-hold-theirown/.

6. Amy Gunia, "A Brief History of Protest in Post-Handover Hong Kong”, Time, https:/ / time.com/5606212/hong-kong-history-mass-demonstrations-protest/. This turnout equates to $7.4 \%$ of the entire population of Hong Kong. In comparison, the Black Lives Matter movement had an estimated 15-26 million turnout, which is $4.5-7.8 \%$ of the population in USA. Larry Buchanan, Quoctrung Bui, and Jugal 
K. Patel, "Black Lives Matter May Be the Largest Movement in U.S. History," The New York Times, https://www.nytimes.com/interactive/2020/07/03/us/georgefloyd-protests-crowd-size.html.

7. Picked up by CNN (2003), NYT by Bradsher (2003), VOA (2003.

8. Amy Gunia, "A Brief History of Protest in Post-Handover Hong Kong". The chairman of the Liberal Party resigned abruptly after the protests, causing the bill to be shelved indefinitely.

9. Joshua will be a recurring figure, leading numerous protests over the years and founding Demosisto, a pro-democracy political organization before being arrested and is currently serving a 13-month jail sentence.

10. Anne M. Roantree and Lisa Jucca, “Thousands denounce HSBC board member's likening of Hong Kong people to freed slaves," Reuters, https://www.reuters.com/ article/hongkong-china/thousands-denounce-hsbc-board-members-likening-ofhong-kong-people-to-freed-slaves-idINKBN0IK1AD20141031.

11. Enda Curran, "Hong Kong Police Use of Tear Gas on Pro-Democracy Protesters Is Questioned," The Wall Street Journal, https://www.wsj.com/articles/hong-kongpolice-use-of-tear-gas-on-pro-democracy-protesters-is-questioned-1411991105.

12. Victoria T. Hui, "Hong Kong's Umbrella Movement: The Protests and Beyond", Journal of Democracy, 26,2 (2015): 111-121, https://www.journalofdemocracy.org/ articles/hong-kongs-umbrella-movement-the-protests-and-beyond. The Umbrella Revolution was coined for protestors use of yellow umbrellas to defend themselves from pepper spray and the aforementioned tear gas employed by police forces. 
13. Chris Lau et al., "Shots fired and bricks thrown: Hong Kong tense after Mong Kok mob violence on first day of Lunar New Year," South China Morning Post, https:/ /www.scmp.com/news/hong-kong/law-crime/article/1910845/shots-firedand-bricks-thrown-hong-kong-tense-after-mong.

14. SCMP Reporters, "As it happened: Estimated 1.7 million people attend peaceful Hong Kong anti-government rally,“ South China Morning Post, https://www.scmp. com/news/hong-kong/politics/article/3022772/anti-government-protesters-hongkong-flock-victoria-park.

15. Holmes Chan, "Hong Kong police arrest 51 who 'claimed to be medics or journalists' near besieged PolyU campus,” Hong Kong Free Press, https:/ / hongkongfp.com/2019/11/18/hong-kong-police-arrest-51-claimed-medicsjournalists-near-besieged-polyu-campus; Yan Zhao and Catherine Lai, "Hong Kong campus protesters defy surrender warnings as over 1,000 arrested in 24 hours," Hong Kong Free Press, https://hongkongfp.com/2019/11/20/hong-kongcampus-protesters-defy-surrender-warnings-1000-arrested-24-hours/.

16. Steven Chase, "Canada calls Hong Kong mass arrests an 'assault on representative democracy'," The Globe and Mail, https://www.theglobeandmail.com/politics/ article-canada-calls-hong-kong-mass-arrests-an-assault-on-representative/.

17. Helen Davidson, "China in darkest period for human rights since Tiananmen, says rights group," The Guardian, https://www.theguardian.com/world/2021/jan/13/ china-in-darkest-period-for-human-rights-since-tiananmen-says-rights-group. 18. Agence France-Presse, "Hong Kong pro-democracy movement nominated for 
Nobel peace prize by US lawmakers," The Guardian, https://www.theguardian. com/world/2021/feb/04/hong-kong-pro-democracy-movement-nominated-fornobel-peace-prize-by-us-lawmakers.

19. Helen Davidson, “'Let's learn about national security': Hong Kong rewrites school rules," The Guardian, https://www.theguardian.com/world/2021/feb/05/letslearn-about-national-security-hong-kong-releases-video-for-young-children.

20. Jessie Pang and James Pomfret, "China charges 47 leading Hong Kong prodemocracy activists with subversion," The Globe and Mail, https://www. theglobeandmail.com/world/article-47-of-hong-kongs-leading-pro-democracycampaigners-charged-with/.

21. The Associated Press, “China moves to tighten control over Hong Kong’s electoral system,” CBC News, https://www.cbc.ca/news/world/china-hong-konglawmakers-1.5945202.

22. Yvette Tan, "China NPC: Beijing to overhaul Hong Kong electoral system,” BBC News, https://www.bbc.com/news/world-asia-china-56264117.

23. Wang Chen is the vice-chairman of the National People's Congress, the national legislature of the PRC

24. Agence France-Presse, “Hong Kong’s arts scene shudders as Beijing draws cultural red line," The Guardian, https://www.theguardian.com/world/2021/mar/21/ hong-kongs-arts-scene-shudders-as-beijing-draws-cultural-red-line.

25. Carole J. Peterson and Jan Currie, "Higher Education Restructuring and Academic Freedom in Hong Kong," Policy Futures in Education 6, 5 (2008): 589-600, 
https://journals.sagepub.com/doi/10.2304/pfie.2008.6.5.589.

26. UN Educational, Scientific and Cultural Organization, "Recommendation concerning the Status of Higher-Education Teaching Personnel," Unesco Organization, http://portal.unesco.org/en/ev.php-URL_ID=13144\&URL_ DO=DO_TOPIC\&URL_SECTION=201.html.

27. United Nations, "Universal Declaration of Human Rights," United Nations, December 1948, https:/ /www.un.org/en/about-us/universal-declaration-ofhuman-rights.

28. UN Educational, Scientific and Cultural Organization, "Recommendation concerning the Status of Higher-Education Teaching Personnel."

29. Council of Europe, "Global Forum on Academic Freedom, Institutional Autonomy, and the Future of Democracy," Council of Europe, June 2019, https:/ / rm.coe.int/global-forum-declaration-global-forum-final-21-06-19-003$/ 16809523 \mathrm{e} 5$.

30. Scholars at Risk, "What is the Scholars At Risk Network (SAR)?," Scholars at Risk, https://www.scholarsatrisk.org/faqs/\#1.

31. Esin Düzel, “The Global Attack on Academia,” Global Forum on Academic Freedom, LSE Higher Education (blog), January 7, 2020, https://blogs.lse.ac.uk/ highereducation/2020/01/07/the-global-attack-on-academia/; Pramod K. Nayar, "Why the University and Its Questions Worry the State," The Wire, https:// thewire.in/education/university-question-worry-state.

32. Scholars at Risk, "Academic Freedom Monitoring Project," Scholars at Risk, 
https://www.scholarsatrisk.org/academic-freedom-monitoring-project-index/.

33. Generated Media Inc, "AI Generated Photos," generated.photos, https://generated. photos/faces.

34. "Add Oil" is a popular slogan, used as an encouraging cheer and for support. It was used extensively during the recent Hong Kong protests as well as during the "Umbrella Revolution" to show solidarity with demonstrators and to cheer them on. Translated literally from the Cantonese phrase, it means to "keep at it" and to "keep working hard". 


\section{BIBLIOGRAPHY}

Agence France-Presse. "Hong Kong pro-democracy movement nominated for Nobel peace prize by US lawmakers." The Guardian, February 4, 2021. https:/ / www.theguardian.com/world/2021/feb/04/hong-kong-pro-democracymovement-nominated-for-nobel-peace-prize-by-us-lawmakers. . "Hong Kong's arts scene shudders as Beijing draws cultural red line." The

Guardian, March 21, 2021. https://www.theguardian.com/world/2021/ mar/21/hong-kongs-arts-scene-shudders-as-beijing-draws-cultural-red-line.

Bradsher, Keith. "Hundreds of Thousands in Hong Kong Protest Security Laws." The New York Times, July 1, 2003. https://www.nytimes.com/2003/07/01/ international/asia/hundreds-of-thousands-in-hong-kong-protest-security-laws. html.

Britannica, The Editors of Encyclopedia. "The Treaty of Nanjing.” Encyclopedia Britannica, February 9, 2018. https://www.britannica.com/event/Treaty-ofNanjing.

Buchanan, Larry, Quoctrung Bui, and Jugal K Patel. "Black Lives Matter May Be the Largest Movement in U.S. History." The New York Times, July 3, 2020. https:/ /www.nytimes.com/interactive/2020/07/03/us/george-floyd-protestscrowd-size.html.

Chan, Holmes. "Hong Kong police arrest 51 who 'claimed to be medics or journalists' near besieged PolyU campus.” Hong Kong Free Press, November 18, 2019. https://hongkongfp.com/2019/11/18/hong-kong-police-arrest-51-claimedmedics-journalists-near-besieged-polyu-campus. 
Chase, Steven. "Canada calls Hong Kong mass arrests an 'assault on representative democracy'." The Globe and Mail, January 8, 2021. https:/ /www.

theglobeandmail.com/politics/article-canada-calls-hong-kong-mass-arrests-anassault-on-representative/.

Cheng, Kris. “Hongkongers identifying as 'Chinese' at record low; under 10\% of youth 'proud' to be citizens - poll.” Hong Kong Free Press, June 28, 2019. https://hongkongfp.com/2019/06/28/hongkongers-identifying-chineserecord-low-10-youth-proud-citizens-poll/.

Chris Lau, Danny Lee, Joyce Ng, Clifford Lo, Nikki Sun, and Stuart Lau. 'Shots fired and bricks thrown: Hong Kong tense after Mong Kok mob violence on first day of Lunar New Year.” South China Morning Post, February 9, 2016. https://www.scmp.com/news/hong-kong/law-crime/article/1910845/shotsfired-and-bricks-thrown-hong-kong-tense-after-mong.

Cable News Network. "Huge protest fills HK streets." CNN, July 2, 2003. https:// edition.cnn.com/2003/WORLD/asiapcf/east/07/01/hk.protest/.

Council of Europe. "Global Forum on Academic Freedom, Institutional Autonomy, and the Future of Democracy." Council of Europe, June 21, 2019. https:// rm.coe.int/global-forum-declaration-global-forum-final-21-06-19-003$/ 16809523 \mathrm{e} 5$.

Curran, Edna. "Hong Kong Police Use of Tear Gas on Pro-Democracy Protesters Is Questioned." The Wall Street Journal, September 29, 2014. https:/ /www. wsj.com/articles/hong-kong-police-use-of-tear-gas-on-pro-democracyprotesters-is-questioned-1411991105.

Davidson, Helen. "China in darkest period for human rights since Tiananmen, says rights group." The Guardian, January 13, 2021. https://www.theguardian.com/ world/2021/jan/13/china-in-darkest-period-for-human-rights-since- 
tiananmen-says-rights-group.

. "'Let's learn about national security': Hong Kong rewrites school rules." The

Guardian, February 5, 2021. https://www.theguardian.com/world/2021/

feb/05/lets-learn-about-national-security-hong-kong-releases-video-for-young-

children.

Düzel, Esin. "The Global Attack on Academia." The London School of

Economics and Political Science Blog, January 7, 2020. https://blogs.lse.ac.uk/ highereducation/2020/01/07/the-global-attack-on-academia/.

Generated Media, Inc. “AI Generated Photos.” Accessed March 20, 2021. https:// generated.photos/faces.

Gunia, Amy. "A Brief History of Protest in Post-Handover Hong Kong.” Time, June 20, 2019. https://time.com/5606212/hong-kong-history-massdemonstrations-protest/.

Hui, Victoria Tin-bor. "Hong Kong’s Umbrella Movement: The Protests and Beyond.” Journal of Democracy 26, no. 2 (2015): 111-21. https:/ /www.

journalofdemocracy.org/articles/hong-kongs-umbrella-movement-the-protestsand-beyond/.

Lao, Yan Zhao, and Catherine Lai. 2019. "Hong Kong campus protesters defy surrender warnings as over 1,000 arrested in 24 hours." Hong Kong Free Press, November 20, 2019. https://hongkongfp.com/2019/11/20/hong-kongcampus-protesters-defy-surrender-warnings-1000-arrested-24-hours/.

Lau, Chris, Danny Lee, Joyce Ng, Clifford Lo, Nikki Sun, and Stuart Lau. "Shots fired and bricks thrown: Hong Kong tense after Mong Kok mob violence on first day of Lunar New Year.” South China Morning Post, February 9, 2016. https://www.scmp.com/news/hong-kong/law-crime/article/1910845/shotsfired-and-bricks-thrown-hong-kong-tense-after-mong. 
Nayar, Pramod K. "Why the University and Its Questions Worry the State." The Wire, November 19, 2019. https://thewire.in/education/university-question-worrystate.

Pang, Jesse, and James Pomfret. 2021. "China charges 47 leading Hong Kong prodemocracy activists with subversion." The Globe and Mail, February 28, 2021. https://www.theglobeandmail.com/world/article-47-of-hong-kongs-leadingpro-democracy-campaigners-charged-with/.

People's Republic of China. "Full Text of the Constitution and the Basic Law." December 4, 1982. https://www.basiclaw.gov.hk/en/basiclawtext/index.html. Peterson, Carole J., and Jan Currie. "Higher Education Restructuring and Academic Freedom in Hong Kong." Policy Futures in Education 6, no. 5 (October 2008): 589-600. https://doi.org/10.2304/pfie.2008.6.5.589.

Reporters, SCMP. “As it happened: Estimated 1.7 million people attend peaceful Hong Kong anti-government rally.” South China Morning Post, August 18, 2019. https://www.scmp.com/news/hong-kong/politics/article/3022772/antigovernment-protesters-hong-kong-flock-victoria-park.

Roantree, Anne Marie, and Lisa Jucca. “Thousands denounce HSBC board member's likening of Hong Kong people to freed slaves.” Reuters, October 31, 2014. https://www.reuters.com/article/hongkong-china/thousandsdenounce-hsbc-board-members-likening-of-hong-kong-people-to-freed-slavesidINKBN0IK1AD20141031.

Scholars at Risk. "FAQs." Accessed February 22, 2021. https:/ /www.scholarsatrisk.org/ faqs/.

Scholars at Risk. "Academic Freedom Monitoring Project.” Accessed March 28, 2021. https://www.scholarsatrisk.org/academic-freedom-monitoring-project-index/. Sing, Ming. "Hong Kong's Democrats Hold Their Own.” Journal of Democracy 20, 
no. 1 (2009): 98-112.

Tan, Yvette. "China NPC: Beijing to overhaul Hong Kong electoral system.” British Broadcasting Corporation, March 5, 2021. https://www.bbc.com/news/worldasia-china-56264117.

The Associated Press. "China moves to tighten control over Hong Kong's electoral system.” Canadian Broadcasting Corporation, March 11, 2021. https://www. cbc.ca/news/world/china-hong-kong-lawmakers-1.5945202.

Tsang, Steve. A Modern History of Hong Kong. London: I.B. Tauris, 2007.

UN Educational, Scienctific and Cultural Organization. "Recommendation concerning the Status of Higher-Education Teaching Personnel." November 11, 1997. http://portal.unesco.org/en/ev.php-URL_ID=13144\&URL_DO=DO_ TOPIC\&URL_SECTION=201.html.

United Nations General Assembly. Resolution 217 A. "Universal Declaration of Human Rights.” December 10, 1948. https://www.un.org/en/about-us/ universal-declaration-of-human-rights.

Vittachi, Nury. "Hong Kong, City of Broken Promises." Asia Sentinel, September 05, 2014. https://www.asiasentinel.com/p/hong-kong-city-broken-promises.

VOA. "Hong Kong Protestors Demand Resignation of Chief Executive - 2003-07-10." Voice of America, October 30, 2009. https://www.voanews.com/archive/ hong-kong-protestors-demand-resignation-chief-executive-2003-07-10. 
91 